\title{
REVIEW
}

\section{Vitamin D, PCOS and androgens in men: a systematic review}

\author{
Christian Trummer, Stefan Pilz, Verena Schwetz, Barbara Obermayer-Pietsch and Elisabeth Lerchbaum
}

Department of Internal Medicine, Division of Endocrinology and Diabetology, Medical University of Graz, Graz, Austria

Correspondence should be addressed to E Lerchbaum: elisabeth.lerchbaum@medunigraz.at

\section{Abstract}

Background: Accumulating evidence from animal and human studies suggests that vitamin $D$ is involved in many functions of the reproductive system in both genders. Aim: The aim of this review was to provide an overview on the effects of vitamin $D$ on polycystic ovary syndrome (PCOS) in women and androgen metabolism in men. Methods: We performed a systematic literature search in PubMed for relevant English language publications published from January 2012 until September 2017.

Results and discussion: The vitamin D receptor and vitamin D-metabolizing enzymes are found in reproductive tissues of women and men. In women, vitamin D status has been associated with several features of PCOS. In detail, cross-sectional data suggest a regulatory role of vitamin D in PCOS-related aspects such as ovulatory dysfunction, insulin resistance as well as hyperandrogenism. Moreover, results from randomized controlled trials (RCTs) suggest that vitamin D supplementation may be beneficial for metabolic, endocrine and fertility aspects in PCOS. In men, vitamin D status has been associated with androgen levels and hypogonadism. Further, there is some evidence for a favorable effect of vitamin D supplementation on testosterone concentrations, although others failed to show a significant effect on testosterone levels. Conclusion: In summary, vitamin D deficiency is associated with adverse fertility outcomes including PCOS and hypogonadism, but the evidence is insufficient to establish causality. High-quality RCTs are needed to further evaluate the effects of vitamin D supplementation in PCOS women as well as on androgen levels in men.

\author{
Key Words \\ - vitamin D \\ - polycystic ovary syndrome \\ - testosterone \\ - randomized controlled \\ trial \\ - systematic review
}

\section{Introduction}

Considering the high prevalence of an insufficient vitamin $D$ status in many populations as well as the potential link between low vitamin D status and adverse health outcomes (1), vitamin D deficiency is classified as an important public health problem (2). Vitamin D has been well known for its role in maintaining calcium homeostasis and promoting bone mineralization (2). Beyond the established relationship between vitamin $\mathrm{D}$ deficiency and musculoskeletal diseases, evidence is accumulating that vitamin $\mathrm{D}$ deficiency is also a risk marker for insulin resistance (3), cardiovascular disease (4), infectious and autoimmune diseases (1), cancer (5), increased mortality (2) as well as decreased fertility (6).

Infertility is a complex disorder with significant medical, psychosocial and economic aspects (7), which affects about $15 \%$ of couples (8). One major cause of female infertility is polycystic ovary syndrome (PCOS). Women affected by PCOS frequently suffer from oligoor anovulation as well as from obesity and insulin resistance $(9,10)$. Thus, PCOS women are considered to be at high risk for metabolic diseases such as type 2 diabetes mellitus (DM) and metabolic syndrome as well as for cardiovascular diseases (11). Interestingly, there is

$$
\begin{array}{lr}
\text { http://www.endocrineconnections.org } & \odot 2018 \text { The authors } \\
\text { https://doi.org/10.1530/EC-18-0009 } & \text { Published by Bioscientifica Ltd }
\end{array}
$$


accumulating evidence showing an association of vitamin D status with pathogenesis, signs and symptoms of PCOS $(3,12)$.

Besides the above mentioned important causes of female infertility, population-based studies found that in $30-40 \%$ of infertile couples, the underlying cause is the male factor (13). One major aspect regarding male fertility is the complex interaction between pituitary gland and testis. Of note, testosterone is not only an important regulator of spermatogenesis, but decreasing testosterone levels might also contribute to many adverse aspects of male aging (14). It is therefore worth mentioning that similar to the above stated association of low vitamin D status with adverse health outcomes, several lines of evidence suggest that low testosterone levels are associated with adverse events including higher cardiovascular and all-cause mortality $(15,16,17,18)$. In this context, it should be noted that androgen and vitamin D metabolism seem to be associated $(19,20)$.

Considering the potential link between vitamin D and human fertility, we performed this systematic review summarizing current literature on vitamin D, PCOS and androgen metabolism in men.

\section{Methods}

We performed a systematic literature search in PubMed for relevant English language publications published from January 2012 until September 2017. We used the following search terms: 'vitamin $\mathrm{D}^{\prime}$ and 'polycystic ovary syndrome', 'vitamin D' and 'PCOS', 'vitamin $\mathrm{D}^{\prime}$ and 'testosterone', 'vitamin $\mathrm{D}^{\prime}$ and 'hypogonadism'. In addition, we also used the search terms '25-hydroxyvitamin D (25(OH) D)', '1,25-dihydroxyvitamin D' and 'calcitriol' instead of vitamin $\mathrm{D}$. We also used listed references from selected articles to expand the search.

We start with a short overview on the background and potential mechanisms explaining the relationship of vitamin D and PCOS. Next, we will discuss observational studies on vitamin D and PCOS, and we will then highlight results of intervention studies investigating vitamin D effects on PCOS. In the second part of the review, we will provide some information on possible mechanisms explaining the link of vitamin D with androgen metabolism in men. Further, we give an overview on observational studies on vitamin D and androgen levels. Finally, we will again focus on intervention studies analyzing vitamin D effects on androgen levels in men. The role of vitamin D in spermatogenesis and other aspects of female fertility

$$
\text { http://www.endocrineconnections.org }
$$

(such as endometriosis or in vitro fertilization) as well as earlier articles on vitamin D and fertility have been comprehensively reviewed elsewhere $(6,21,22)$ and are not included here.

\section{Vitamin D and PCOS}

\section{Background and mechanisms}

The vitamin D receptor (VDR) can be found across several tissues within the female reproductive system. VDR mRNA is expressed in ovarian, deciduae, placenta and endometrium cells $(6,23,24)$. Furthermore, calcitriol $\left(1,25[\mathrm{OH}]_{2}\right.$ vitamin D) directly leads to the production of estrogen and progesterone in cultured human ovary and placenta cells $(24,25)$, thus possibly potentiating granulosa cell luteinization and leading to an improved endometrial environment (26). Further, there exists a relationship between vitamin $\mathrm{D}$ and markers of ovarian reserve, especially anti-Müllerian hormone (AMH). AMH is a glycoprotein that plays a fundamental role in the regression of Müllerian ducts in male embryos, while in its absence, Müllerian ducts develop into female inner reproductive organs. In females, it is secreted by granulosa cells of small follicles in the ovary and is considered an ideal tool for the assessment of the ovarian follicular reserve during a woman's reproductive life (27). Interestingly, AMH shows seasonal variations correlating with seasonal changes in serum 25(OH)D (28). Moreover, it has been shown that cholecalciferol (vitamin D3) supplementation might prevent seasonal AMH changes (28).

In PCOS, ovarian physiology is closely connected to the commonly observed metabolic disturbances of the syndrome $(3,26)$. Furthermore, vitamin D deficiency appears to be related to several of these metabolic features of the PCOS phenotype $(3,26,29)$. Several studies showed a higher prevalence of insufficient vitamin $\mathrm{D}$ status (defined as $25[\mathrm{OH}] \mathrm{D}$ concentrations $<75 \mathrm{nmol} / \mathrm{L}$ ) in PCOS women when compared to control women matched for age and body mass index (BMI) $(29,30,31)$.

Vitamin D status may play an important role in the development of insulin resistance in PCOS, while vitamin D supplementation might improve insulin sensitivity as well as serum androgen concentrations (32, 33, 34). In a cross-sectional study by Wehr and coworkers (3), $25(\mathrm{OH}) \mathrm{D}$ concentrations were an independent predictor for homeostasis model assessment-insulin resistance (HOMA-IR) and BMI. Serum concentrations of $25(\mathrm{OH})$ $\mathrm{D}$ were negatively correlated with adiposity markers, including BMI and central obesity $(35,36)$. In this context, 
it should be noted that results derived from a Mendelian Randomization study suggest that low 25(OH)D levels are a consequence of obesity, but it is unlikely that vitamin D deficiency causes obesity (37). Interestingly, the observed association between vitamin D deficiency and insulin resistance does not seem to be confounded by obesity, since insulin resistance appears to be related to severe vitamin D deficiency regardless of BMI or waist-to-hip ratio in PCOS women (38). Therefore, alternative mechanisms to explain the association between vitamin D deficiency and insulin resistance were proposed: As the transcription of the insulin gene is activated by $1,25(\mathrm{OH})_{2} \mathrm{D}$ and the vitamin D-responsive element is present in the promoter region of the human insulin gene $(39,40)$, vitamin D may stimulate the expression of insulin receptors, thus improving insulin responsiveness for glucose transport (6). Furthermore, vitamin D is involved in calcium homeostasis, which is important for intracellular insulinmediated procedures in insulin-responsive tissues (41).

Polymorphisms of the VDR could be involved in the pathogenesis of PCOS or increase the susceptibility for its development $(42,43)$. This mechanism is supported by the fact that $1,25[\mathrm{OH}]_{2} \mathrm{D}$ directly or indirectly controls several hundred genes, including some with relevance for glucose homeostasis $(2,41)$. Some VDR-related polymorphisms, i.e. iApa-I, Taq-I, Cdx2, Bsm-I and Fok-I, have been related to metabolic features in PCOS $(29,42)$. Another singlenucleotide polymorphism (rs757343) was associated with the severity of PCOS symptoms, but not with the risk to develop the syndrome itself (44).

Considering the proposed beneficial effects of vitamin D on several metabolic disturbances as well as the above mentioned link between vitamin $\mathrm{D}$, granulosa cell luteinization and improved endometrial

Table 1 Summary of clinical observational studies investigating the association of vitamin $D$ and clinical as well as biochemical parameters in PCOS women.

\begin{tabular}{|c|c|c|c|c|c|c|}
\hline Author & Subjects & Age & Metabolic parameters & $\begin{array}{l}\text { Endocrine } \\
\text { parameters }\end{array}$ & Clinical parameters & Adjustment \\
\hline Ott et al. (52) & $\begin{array}{l}91 \text { PCOS } \\
\text { women }\end{array}$ & $29(19-38)$ years & & & $\begin{array}{l}25(\mathrm{OH}) \mathrm{D} \text { deficiency } \\
\text { significant predictive } \\
\text { parameter for follicle } \\
\text { development and } \\
\text { pregnancy }\end{array}$ & $\begin{array}{l}\text { Age, BMI, LH:FSH } \\
\text { ratio }\end{array}$ \\
\hline Kim et al. (49) & $\begin{array}{l}38 \text { PCOS } \\
\text { women }\end{array}$ & $34.1 \pm 4.6$ years & No correlation & No correlation & No correlation & \\
\hline $\begin{array}{l}\text { Sahin } \\
\text { et al. (51) }\end{array}$ & $\begin{array}{l}50 \text { PCOS } \\
\text { women }\end{array}$ & $27.3 \pm 0.5$ years & $\begin{array}{l}\text { No correlation with } \\
\text { HOMA-IR }\end{array}$ & & & \\
\hline Pal et al. (47) & $\begin{array}{l}540 \text { PCOS } \\
\text { women }\end{array}$ & $28.1 \pm 4.0$ years & $\begin{array}{l}\text { Inverse association } \\
\text { with BMI, fasting } \\
\text { insulin, HOMA-IR } \\
\text { Positive association } \\
\text { with fasting glucose- } \\
\text { insulin ratio }\end{array}$ & $\begin{array}{l}\text { Positive } \\
\text { association } \\
\text { with SHBG }\end{array}$ & $\begin{array}{l}\text { OR for live birth } 0.58 \\
(0.35-0.92) \text { if } 25(\mathrm{OH}) \\
\text { D level was } \\
<75 \mathrm{nmol} / \mathrm{L}, 25(\mathrm{OH}) \mathrm{D} \\
\text { status independent } \\
\text { predictor of live birth } \\
\text { and ovulation after } \\
\text { ovulation induction }\end{array}$ & $\begin{array}{l}\text { Age, BMI, } \\
\text { ovulatory } \\
\text { dysfunction, } \\
\text { ethnicity, baseline } \\
\text { FAl, cycles to } \\
\text { ovulation, } \\
\text { hirsutism, } \\
\text { creatinine, history } \\
\text { of smoking, use } \\
\text { of clomiphene } \\
\text { citrate and } \\
\text { metformin (to } \\
\text { predict live birth) }\end{array}$ \\
\hline $\begin{array}{l}\text { Joham } \\
\text { et al. (48) }\end{array}$ & $\begin{array}{l}42 \text { PCOS } \\
\text { women }\end{array}$ & $28.6 \pm 5.0$ & Association with IR & & & $\begin{array}{l}\text { Body fat } \\
\text { percentage }\end{array}$ \\
\hline $\begin{array}{l}\text { Mishra } \\
\text { et al. (46) }\end{array}$ & $\begin{array}{l}44 \text { PCOS } \\
\text { women }\end{array}$ & $\begin{array}{l}\text { Data not } \\
\text { available }\end{array}$ & $\begin{array}{l}\text { Negative correlation } \\
\text { with HOMA-IR and } \\
\text { insulin, positive } \\
\text { correlation with } \\
\text { HDL-cholesterol }\end{array}$ & $\begin{array}{l}\text { No correlation } \\
\text { with } \\
\text { testosterone }\end{array}$ & & \\
\hline $\begin{array}{l}\text { Kumar } \\
\text { et al. (50) }\end{array}$ & $\begin{array}{l}100 \text { PCOS } \\
\text { women }\end{array}$ & $28.6 \pm 6.3$ years & No correlation & No correlation & No correlation & \\
\hline
\end{tabular}

Data are given as mean \pm S.D. or median (IQR) unless otherwise stated.

25(OH)D, 25-hydroxyvitamin D; BMI, body mass index; FAl, free androgen index; FSH, follicle-stimulating hormone; HDL cholesterol, high-density lipoprotein cholesterol; HOMA-IR, homeostasis model assessment-insulin resistance; IR, insulin resistance; LH, luteinizing hormone; OR, odds ratio; PCOS, polycystic ovary syndrome; SHBG, sex hormone-binding globulin.

http://www.endocrineconnections.org

https://doi.org/10.1530/EC-18-0009 (c) 2018 The authors Published by Bioscientifica Ltd

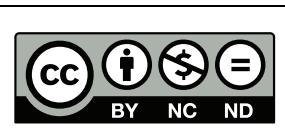

This work is licensed under a Creative Commons Attribution-NonCommercial-NoDerivatives 4.0 International License. 
CONNECTIONS
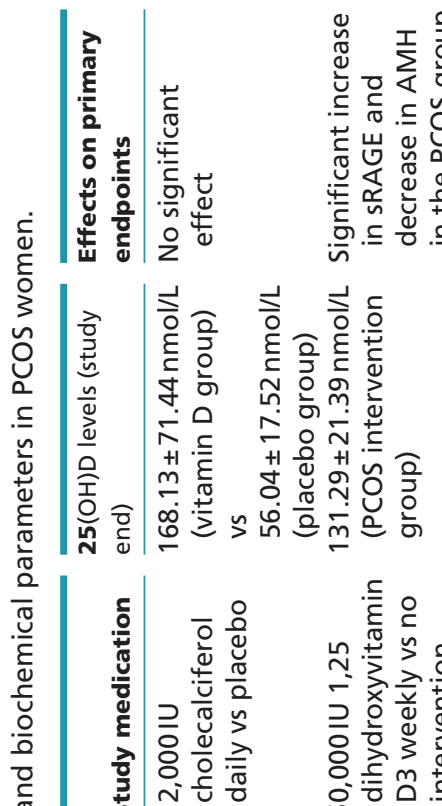
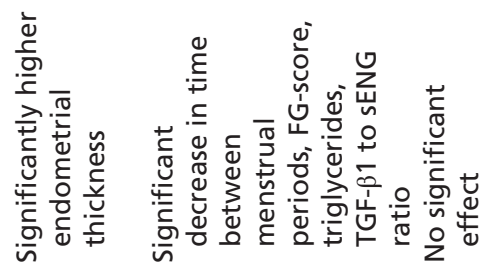

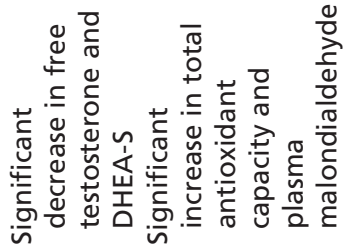

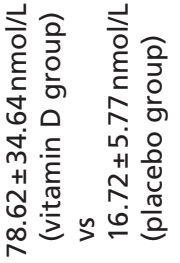

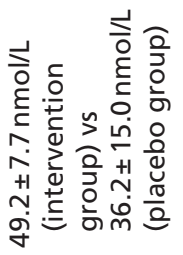

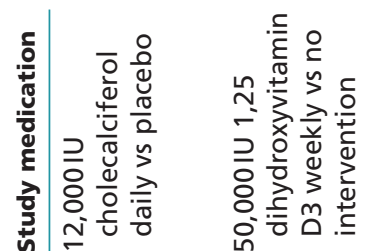
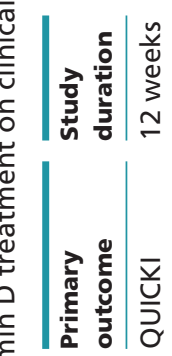

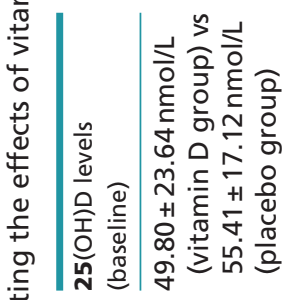

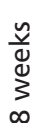

을

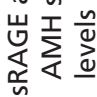

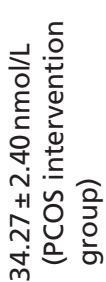

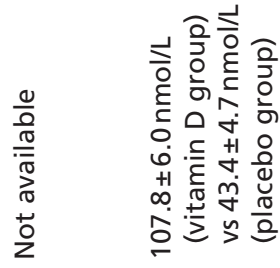

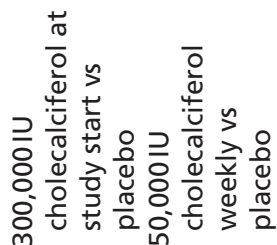

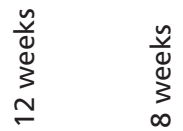

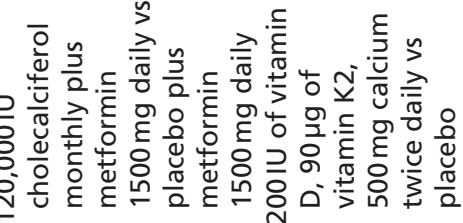

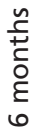

$\stackrel{\check{\varpi}}{\stackrel{\varpi}{\varpi}}$
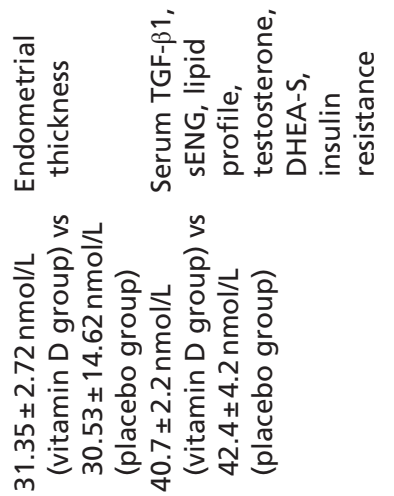

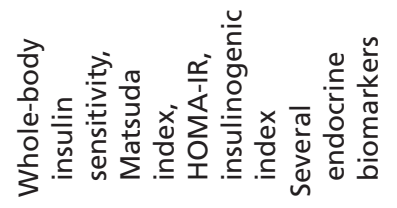
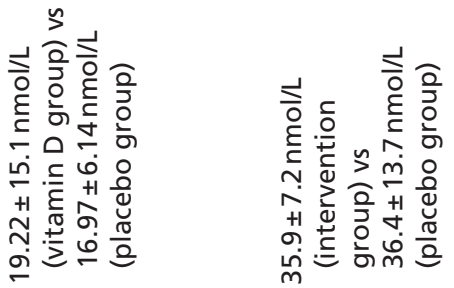
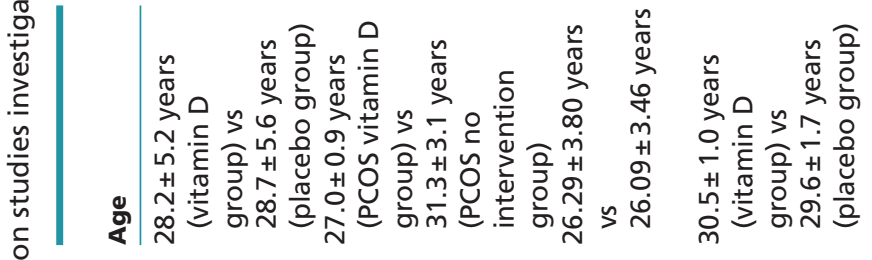

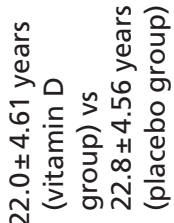

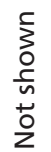

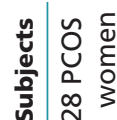

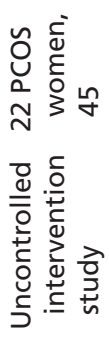

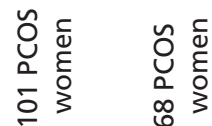

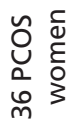

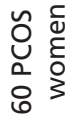

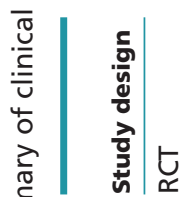

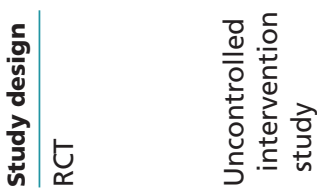

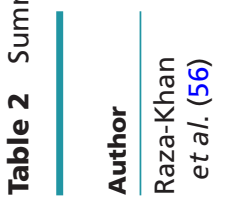

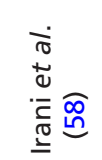

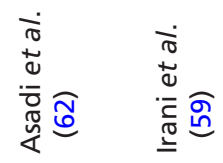

http://www.endocrineconnections.org

https://doi.org/10.1530/EC-18-0009

C) 2018 The authors Published by Bioscientifica Ltd

$\underset{x}{\longleftarrow}$

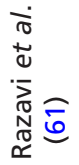




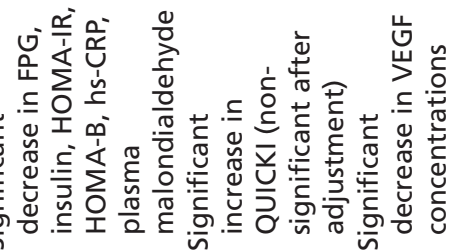

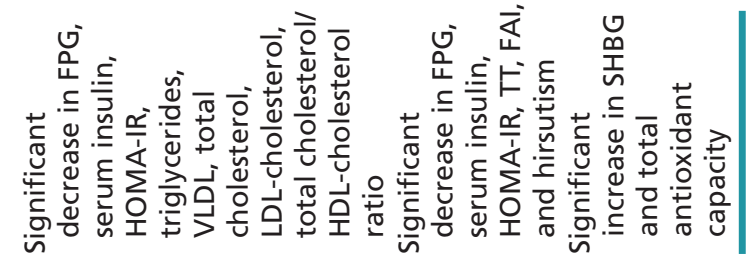

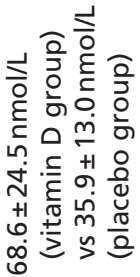

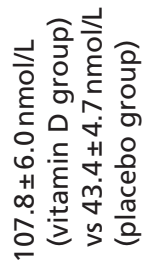

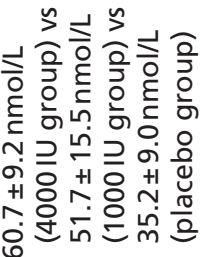

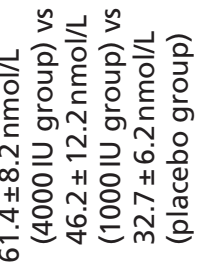

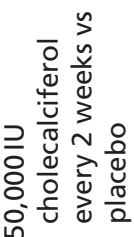

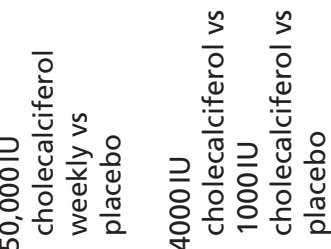

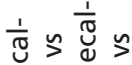

능 중은 증

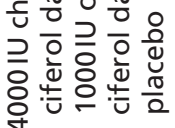

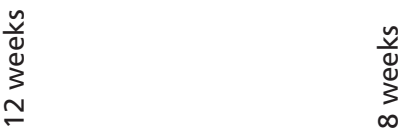

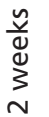

$\stackrel{\tilde{v}}{\frac{\tilde{d}}{3}}$

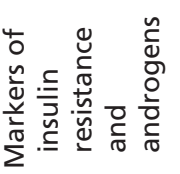

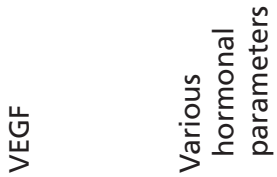

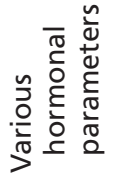

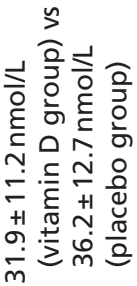

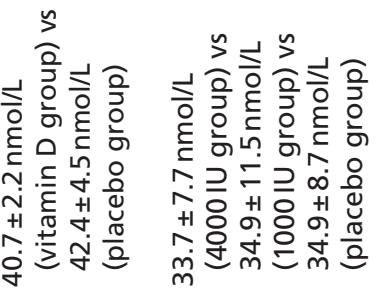

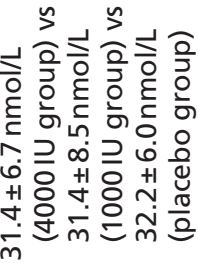

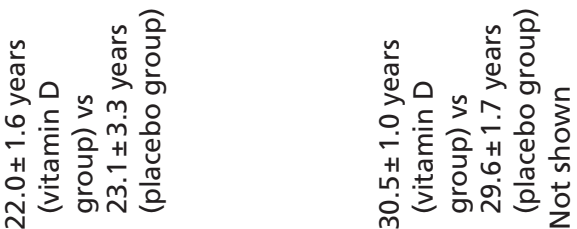

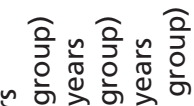

\%

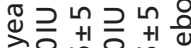

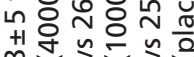

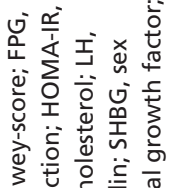

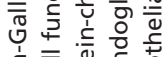

它 $\overline{\bar{Q}}$

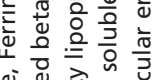

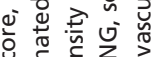

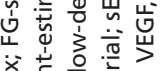

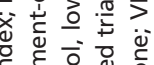

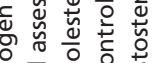

흥 홍 돈

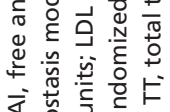

बह

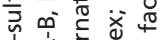

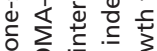

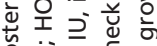

产产论

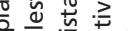

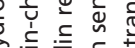

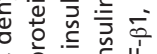

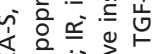

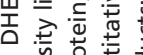

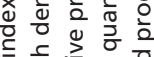

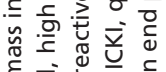

>ำ

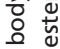

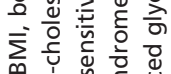

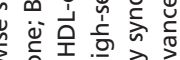

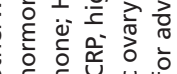

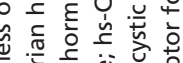

次

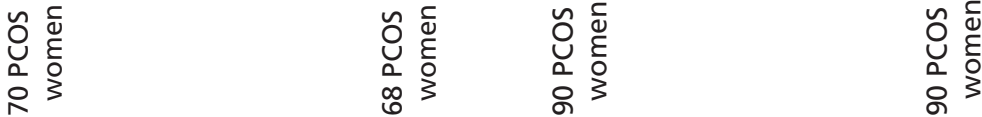

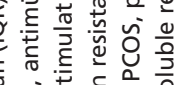

Tे

年 o 운 흥

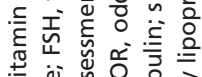

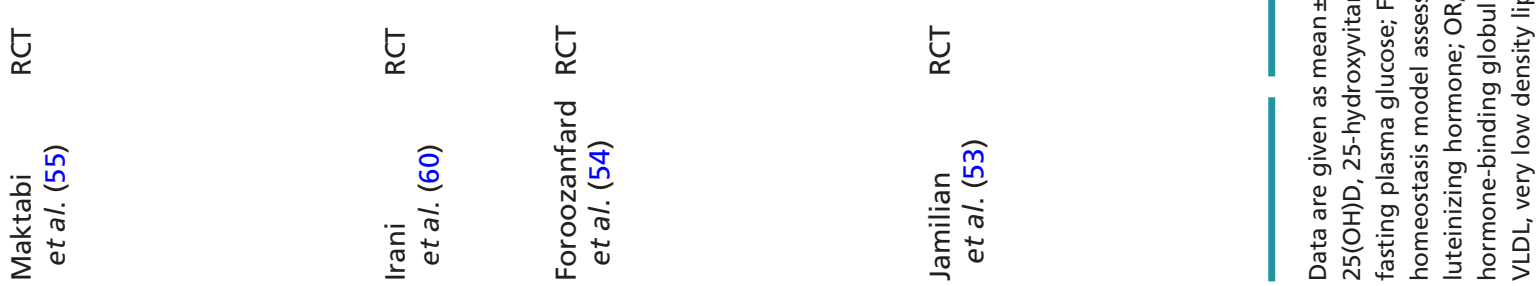


environment (26), it has been speculated that vitamin D supplementation may also improve ovulatory dysfunction and thereby fertility in PCOS patients.

\section{Observational studies}

In the following paragraph, we will discuss observational studies evaluating the association of vitamin D and PCOS. So far, several observational studies investigated a possible association of vitamin D status with biochemical and clinical parameters in PCOS patients (summarized in Table 1). These studies have yielded, however, inconsistent results.

Since insulin resistance is a prominent feature in both PCOS pathophysiology and phenotype (45), several authors aimed to investigate possible associations of vitamin D status with parameters of glycemic control. A study conducted by Mishra and coworkers (46) found negative correlations of $25(\mathrm{OH}) \mathrm{D}$ with insulin concentrations and HOMA-IR. This finding was confirmed by another study (47), which furthermore reported a positive association of $25(\mathrm{OH}) \mathrm{D}$ with fasting glucose:insulin ratio, but no significant correlation with fasting glucose. In another study by Joham and coworkers (48), hyperinsulinemiceuglycemic clamps were performed in 42 PCOS patients and 34 control women. In the PCOS group, 25(OH)D concentrations were significantly associated with insulin resistance measured by hyperinsulinemic-euglycemic clamp independently of body fat percentage, whereas no significant association could be shown within the control group. However, other studies were unable to find a significant association of $25(\mathrm{OH}) \mathrm{D}$ with various parameters of insulin resistance or glycemic control in PCOS patients $(49,50,51)$.

Observational studies investigating possible associations of vitamin $\mathrm{D}$ with endocrine parameters in PCOS women have yielded more unanimous results: Apart from one study reporting a positive correlation with sex hormone-binding globulin (SHBG) (47), other authors were unable to detect a significant correlation of vitamin D with e.g. total testosterone (TT) and free testosterone (FT) (46, $49,50)$, free androgen index (FAI) (49), LH and FSH (50).

In addition to observational studies aiming to evaluate the relationship of vitamin D with endocrine and metabolic parameters, some authors investigated the association of vitamin D status with outcome parameters of fertility treatment. A retrospective analysis of the pregnancy in PCOS I (PPCOS I) randomized controlled trial (RCT), evaluating the effect of $50 \mathrm{mg}$ of clomiphene citrate, metformin $1000 \mathrm{mg}$ twice daily or a combination of both in PCOS women, revealed a 44\% reduced likelihood for live birth if $25(\mathrm{OH}) \mathrm{D}$ concentrations were $<75 \mathrm{nmol} / \mathrm{L}$ (OR 0.58 (0.35-0.92)) (47). Progressive improvement in the odds for live birth was found at thresholds of $\geq 95, \geq 100$ and $\geq 112.5 \mathrm{nmol} / \mathrm{L}$, respectively. Vitamin D status was also an independent predictor of live birth and ovulation after ovulation induction. Similarly, in a prospective cohort study in 91 anovulatory PCOS women who underwent clomiphene citrate stimulation, vitamin $\mathrm{D}$ deficiency (defined as a $25[\mathrm{OH}] \mathrm{D}$ concentration $<25 \mathrm{nmol} / \mathrm{L}$ ) was a significant predictive parameter for both follicle development and pregnancy (52).

\section{Intervention studies}

Within recent years, several interventional trials aimed to investigate potential effects of vitamin D supplementation on metabolic and clinical parameters associated with fertility in PCOS patients. These studies showed a broad variation regarding study design, population, study medication as well as study outcome (summarized in Table 2).

Jamilian and coworkers (53) reported significant decreases in fasting plasma glucose, serum insulin and HOMA-IR in 90 PCOS women after supplementation of 4000 international units (IU) of cholecalciferol daily for 12 weeks in comparison to $1000 \mathrm{IU}$ daily or placebo. A similar RCT conducted by Foroonzanfard and coworkers (54) found a significant effect of 4000 IU cholecalciferol daily over 12 weeks on fasting plasma glucose, serum insulin, HOMA-IR, VLDL, total cholesterol and total cholesterol to HDL-cholesterol ratio compared to groups receiving either $1000 \mathrm{IU}$ of cholecalciferol daily or placebo $(n=90$ PCOS patients, 30 patients per group). Another RCT (55), which investigated the effect of $50000 \mathrm{IU}$ cholecalciferol every 2 weeks over 12 weeks vs placebo in 70 PCOS patients, found significant decreases in fasting plasma glucose, HOMA-IR, homeostasis model assessment-estimated beta cell function (HOMA-B), high-sensitive C-reactive protein and plasma malondialdehyde in the intervention group, whereas no significant change was observed in the placebo group. An increase in quantitative insulin sensitivity check index (QUICKI) in the intervention group did not remain significant after controlling for baseline values of biochemical parameters, age and baseline BMI.

Nevertheless, other interventional studies were unable to find significant effects of vitamin D supplementation on metabolic parameters: Raza-Khan and coworkers (56) aimed to investigate the effect of 12,000 IU cholecalciferol daily vs placebo on insulin sensitivity (QUICKI) over 12 weeks ( $n=28$ PCOS patients). However, there was no significant effect on primary or secondary outcome 
measures (including HOMA-IR, fasting glucose and fasting insulin). Similar results were found in a study by Garg and coworkers (57), where 36 PCOS women either received either $120,000 \mathrm{IU}$ of cholecalciferol monthly or placebo over 6 months. Of note, patients in both groups also received $1500 \mathrm{mg}$ of metformin daily. Several parameters of insulin resistance and insulin sensitivity did not significantly change after vitamin D supplementation, including area under the curve glucose and insulin, insulin:glucose ratio, HOMA-IR, Matsuda index and insulinogenic index. Of note, both of the above mentioned trials $(56,57)$ included a comparatively small patient collective, therefore, potentially limiting the proposed implications derived from these studies.

As elevated AMH levels in PCOS reflect abnormal ovarian folliculogenesis, Irani and coworkers (58) designed an intervention study to investigate the effects of vitamin D supplementation on AMH. In this trial in 22 PCOS patients and 45 healthy control women with vitamin $\mathrm{D}$ deficiency $(25[\mathrm{OH}] \mathrm{D}<50 \mathrm{nmol} / \mathrm{L})$, the participants received $50,000 \mathrm{IU}$ of $1,25(\mathrm{OH})_{2} \mathrm{D}$ over 8 weeks (16 PCOS women and 35 controls) or no treatment. Vitamin D supplementation significantly decreased AMH in PCOS women, but not in controls. In the same study, vitamin D supplementation also significantly increased the level of the soluble receptor for advanced glycation end products (sRAGE) in the PCOS group. Advanced glycation end products might be involved in the pathogenesis of PCOS, and their production is accelerated by DM, insulin resistance and aging, while their binding to sRAGE prevents adverse intracellular effects. Therefore, the authors hypothesized that a rise in sRAGE might improve follicular growth and insulin resistance (58). In another RCT by Irani and coworkers (59) in 68 vitamin D-deficient PCOS women who were randomized to either 50,000 IU of cholecalciferol vs placebo over 8 weeks, a significant decrease in transforming growth factor- $\beta 1$ (TFG- $\beta 1$ ) bioavailability, correlating with a possible improvement in several adverse parameters associated with PCOS was reported. Another finding of that RCT was a significant reduction of interval between menstrual periods and Ferriman-Gallwey scores in the treatment vs the placebo group. A post hoc analysis derived from the same trial (60) found a significant decrease in vascular endothelial growth factor (VEGF) levels correlating with a decrease in triglyceride levels after vitamin D supplementation.

Some studies also reported a significant effect of vitamin D supplementation on androgen concentrations: The already mentioned RCT by Jamilian and coworkers (53) found a significant reduction in TT, FAI and hirsutism after cholecalciferol supplementation. In a study by Razavi and coworkers (61), supplementation of $200 \mathrm{IU}$ cholecalciferol, $90 \mu \mathrm{g}$ of vitamin $\mathrm{K} 2$ and $500 \mathrm{mg}$ of calcium twice daily (vs placebo) led to a significant decrease in FT and dehydroepiandrosterone-sulfate (DHEA-S) in 60 PCOS women.

In addition, Asadi and coworkers (62) aimed to investigate the effects of vitamin D supplementation on the success rate of intra uterine insemination in 110 infertile PCOS women (300,000IU cholecalciferol once vs placebo, 2-month interval between vitamin D administration and insemination). While there was no treatment effect on pregnancy outcomes, the endometrial thickness was significantly higher in the vitamin D when compared to the placebo group.

\section{Meta-analyses}

A recent meta-analysis (63) including 16 studies involving 315 participants on vitamin D effects in PCOS women found that vitamin D supplementation significantly decreased PTH and triglyceride levels but had no effect on HOMA-IR, QUICKI, LDL, DHEAS, FT and TT levels. Another meta-analysis including 9 studies involving 502 PCOS women found that vitamin D significantly improved follicular development in PCOS women (64). Further, a positive effect on menstrual cycle regulation as observed when metformin plus vitamin D was compared with metformin alone. Further, Azadi-Yazdi and coworkers (65) conducted a meta-analysis including 6 clinical trials involving 184 participants investigating vitamin $\mathrm{D}$ effects on androgen levels in PCOS women. The authors found a significant effect on TT levels, whereas no effect was found on FT or SHBG levels.

In conclusion, recent interventional trials investigating the effects of vitamin D supplementation in PCOS have yielded inconsistent results. This may be, at least in part, explained by the differences in study population sizes, study design (e.g. study durations of 8 weeks vs 12 weeks vs 6 months) or by different dosing regimens (e.g. daily administration vs weekly administration vs one-time administration at study start). Additionally, some studies recruited PCOS patients regardless of their vitamin D status while others included only vitamin D-deficient participants (in most cases defined as $25[\mathrm{OH}]$ D concentrations $<50 \mathrm{nmol} / \mathrm{L}$ ), further limiting the comparability and generalizability of currently available interventional trials. Thus, further RCTs in clearly defined large patient collectives are needed to potentially draw conclusions for clinical practice.

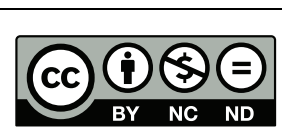

This work is licensed under a Creative Commons Attribution-NonCommercial-NoDerivatives 4.0 International License. 

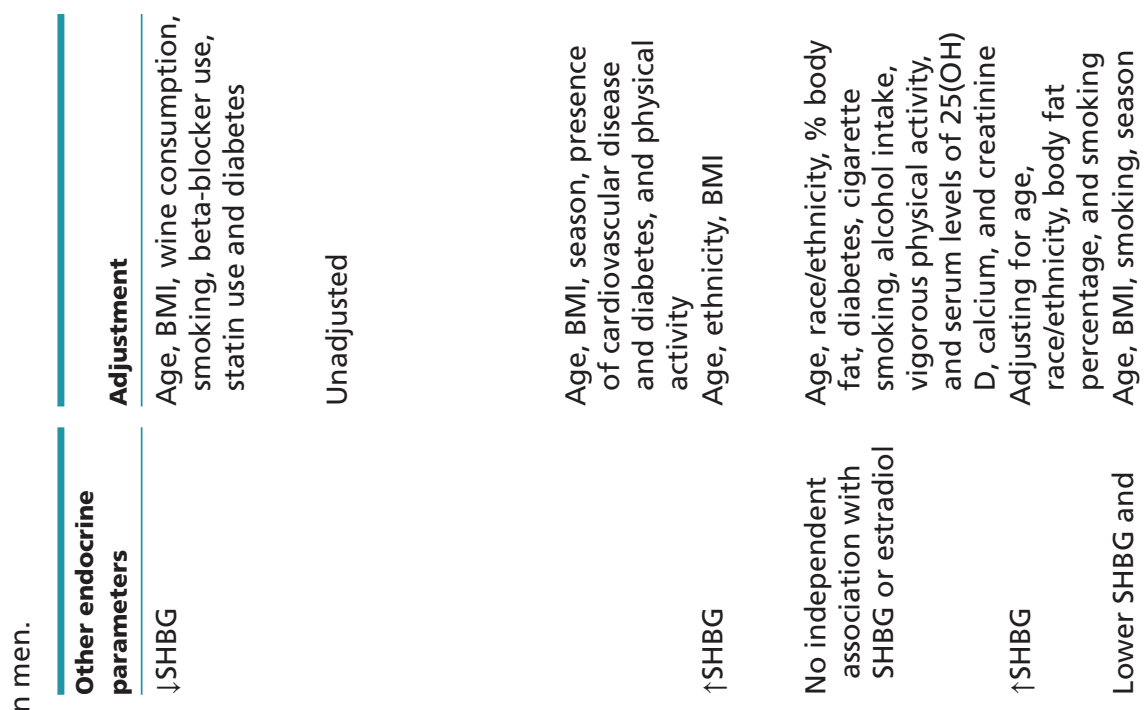

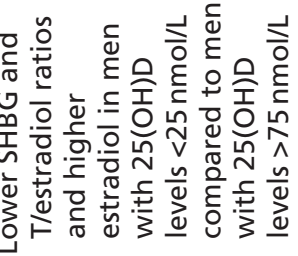
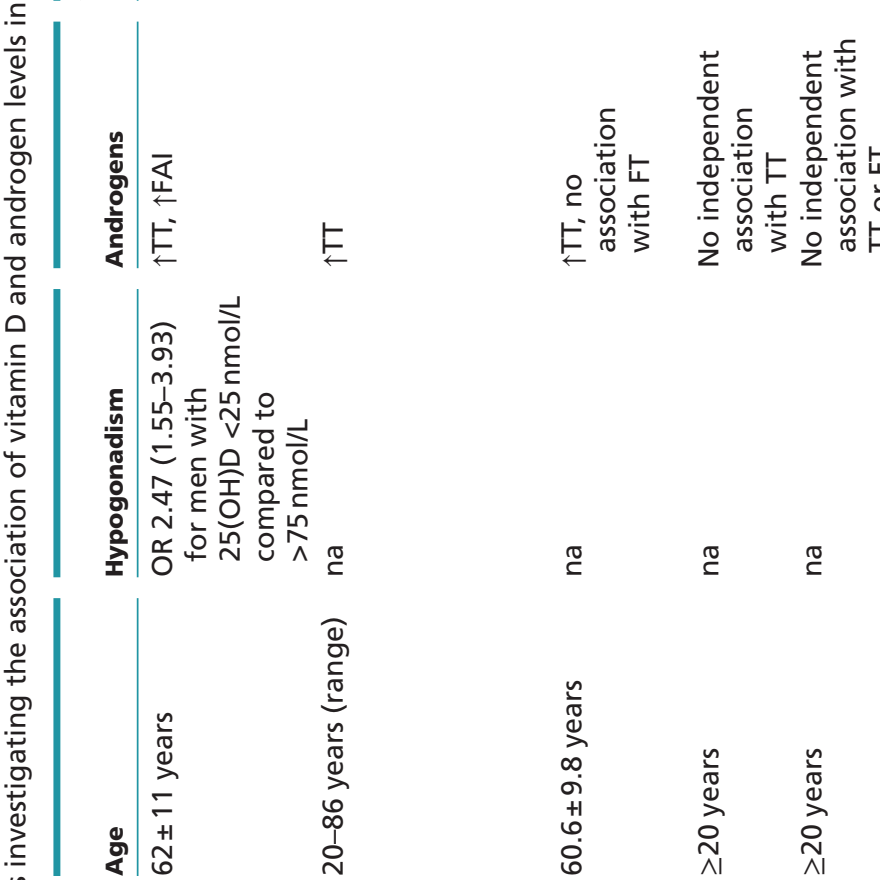

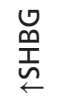

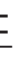

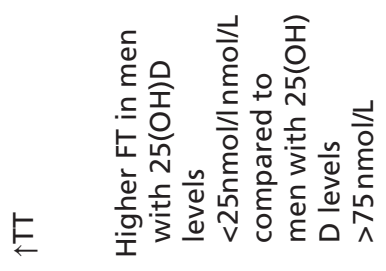

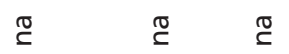

$\stackrel{0}{\check{0}}$

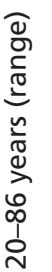

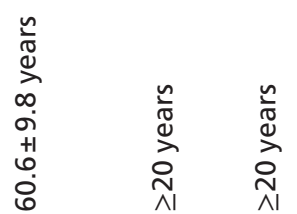

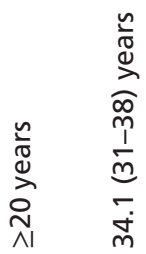

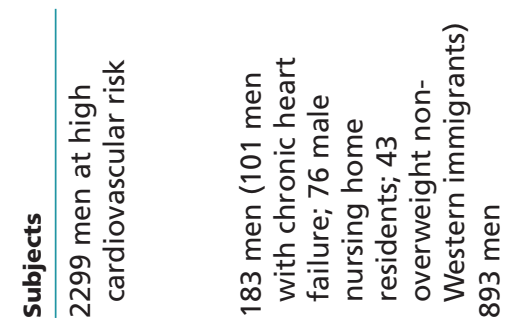

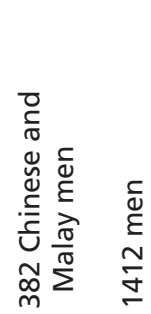

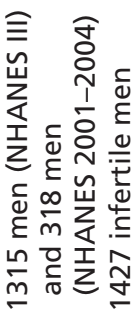
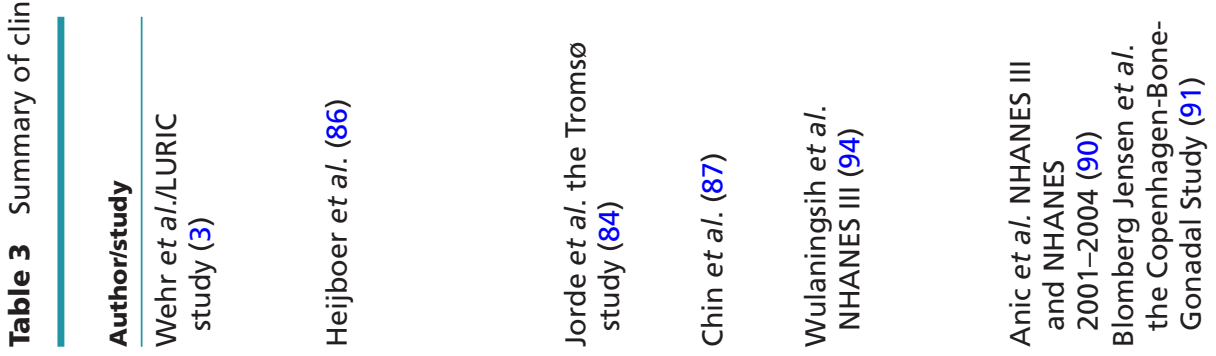

http://www.endocrineconnections.org 


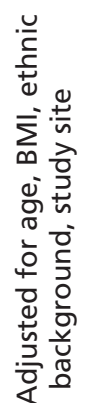
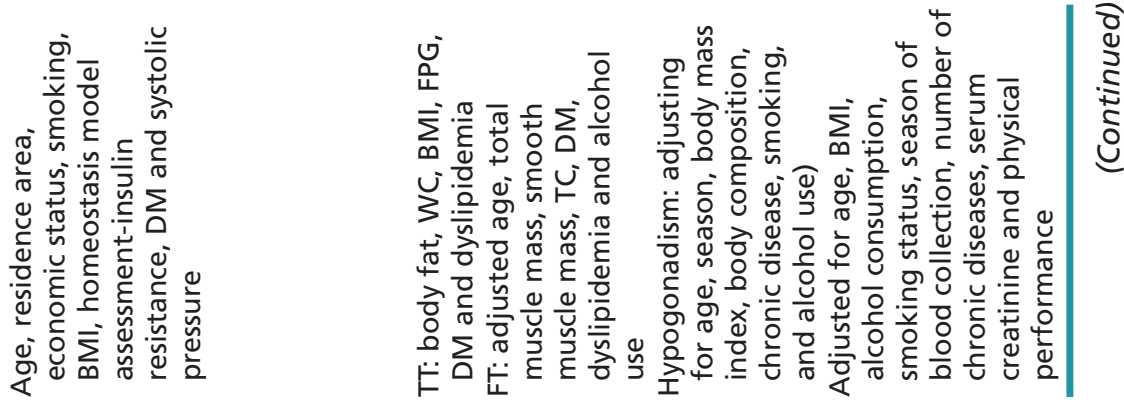

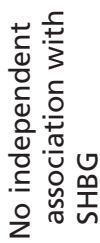

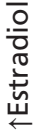

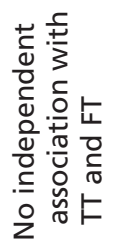

$E$ E

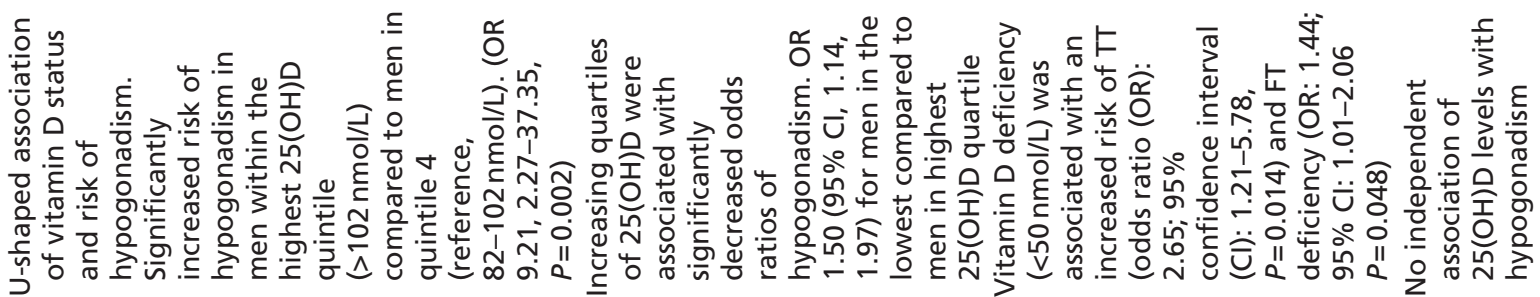

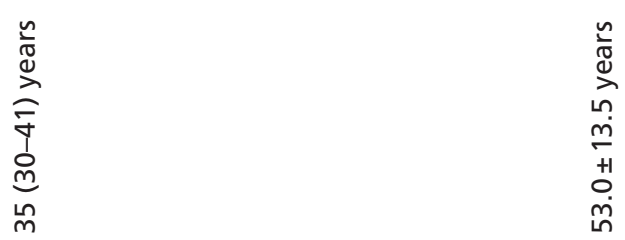

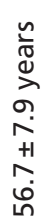
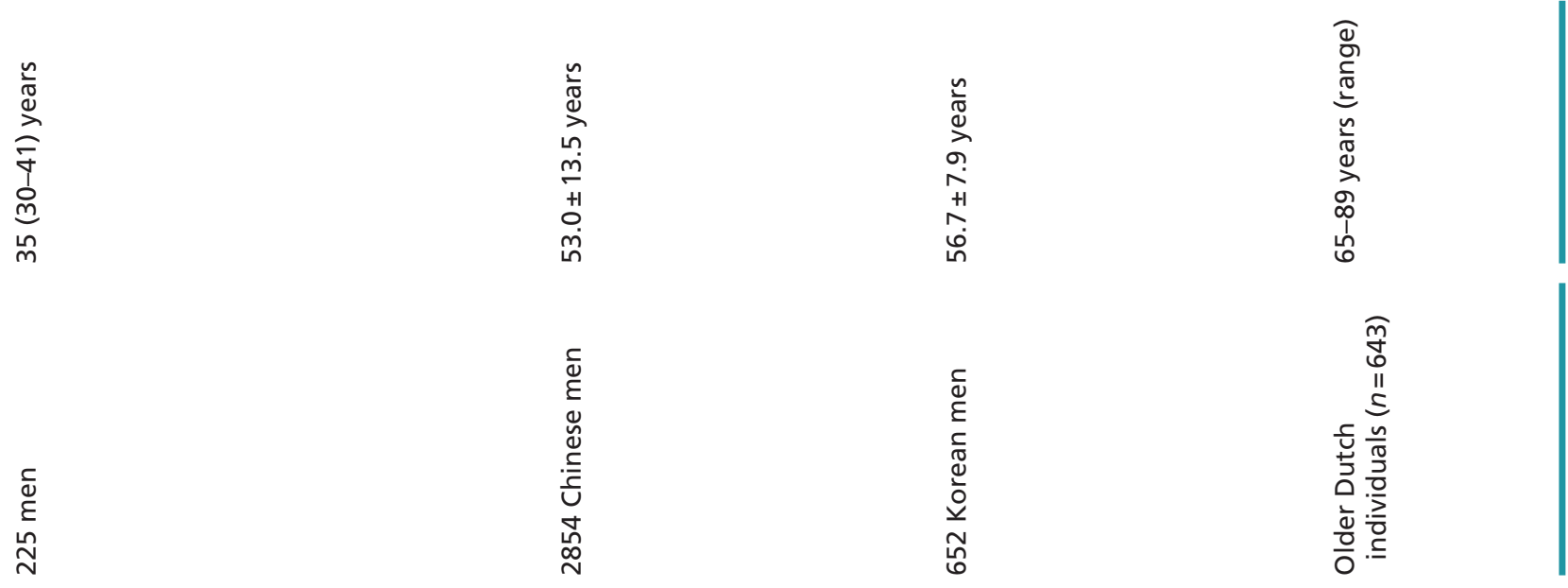

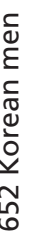
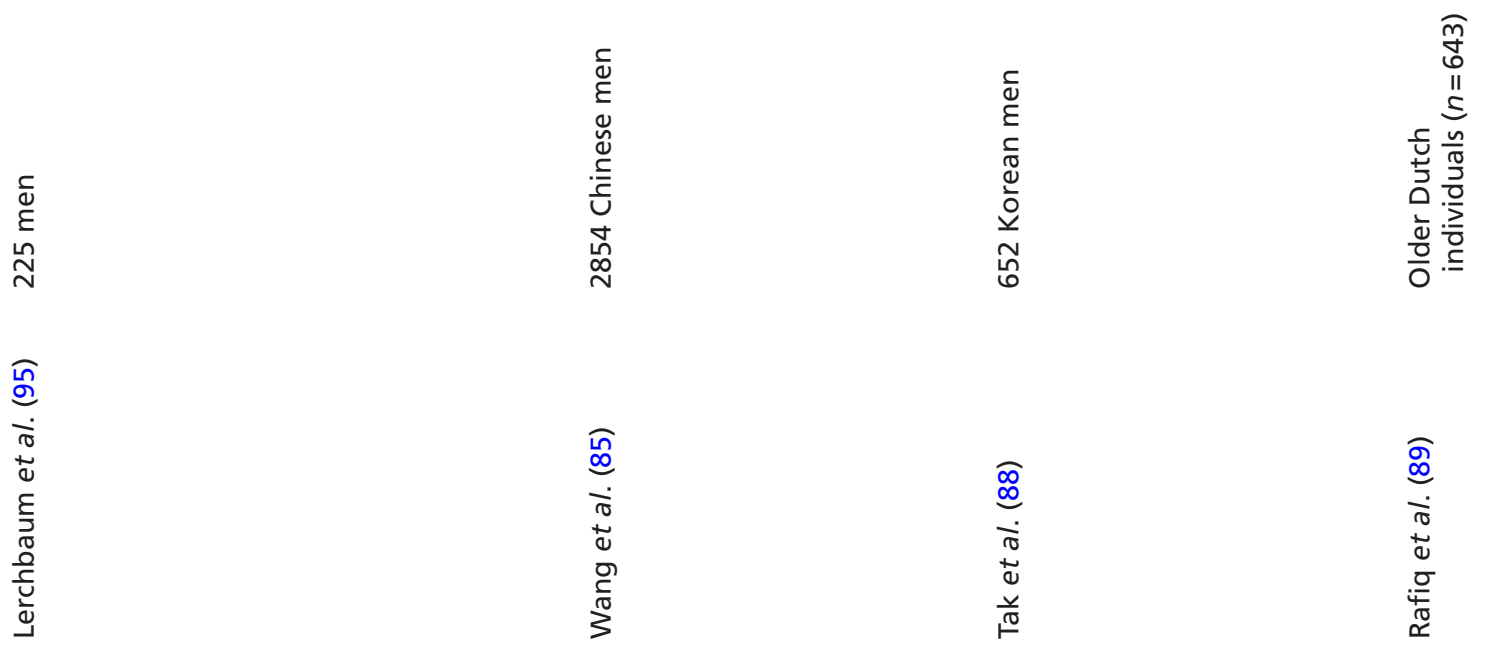

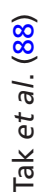

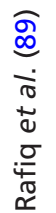



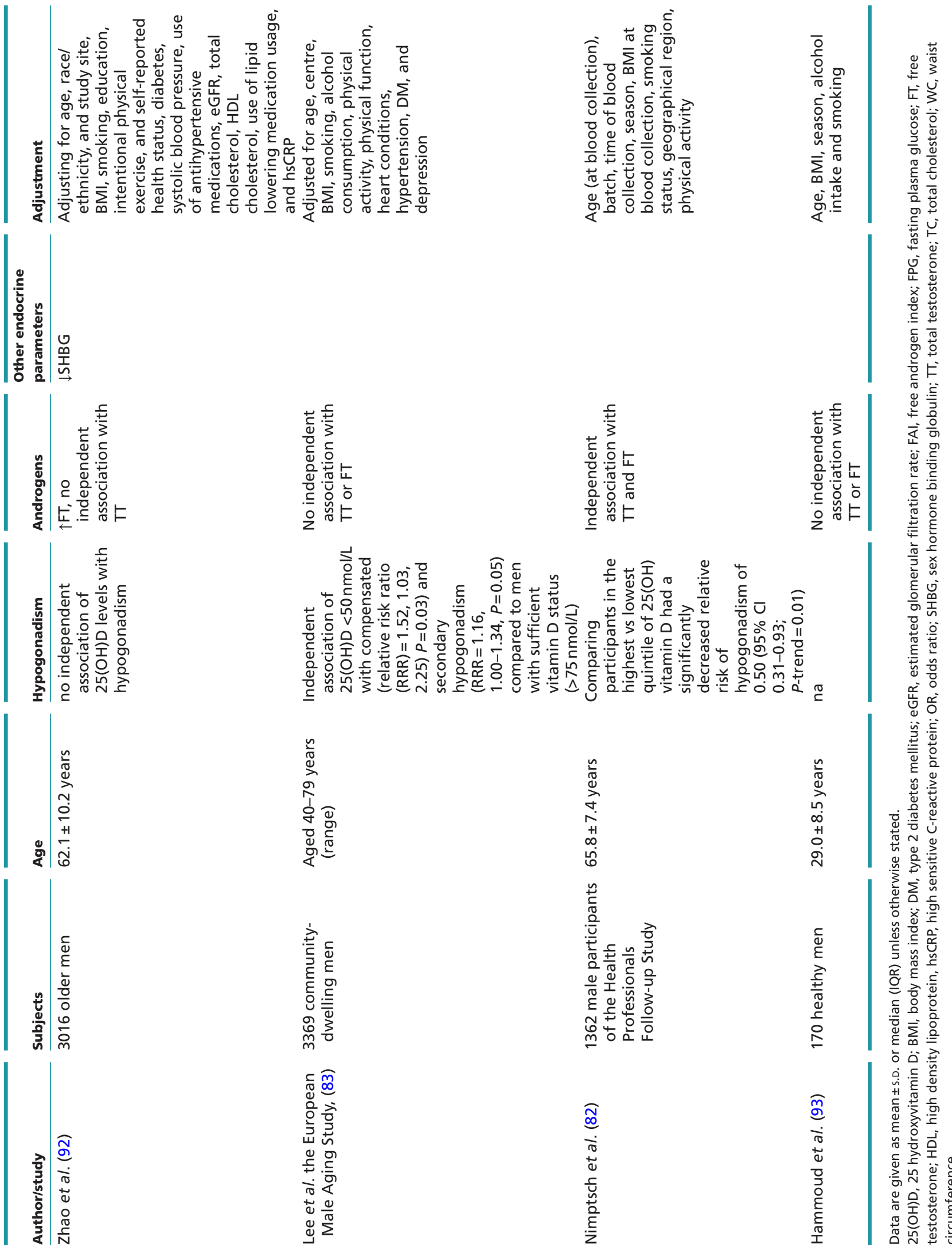
http://www.endocrineconnections.org
https://doi.org/10.1530/EC-18-0009

() 2018 The authors Published by Bioscientifica Ltd 


\section{Vitamin D and testosterone in men}

The association of vitamin $\mathrm{D}$ and testosterone in men has been investigated in various studies including studies on molecular mechanisms, observational studies analyzing the relationship of vitamin D status and circulating testosterone levels in men and clinical intervention studies evaluating the effect of vitamin D treatment on testosterone levels in men. The following paragraph will provide an overview on possible molecular mechanisms regarding the association of vitamin $\mathrm{D}$ and testosterone.

\section{Background and mechanisms}

In addition to its important regulatory effect on spermatogenesis, testosterone is an anabolic hormone with a wide range of beneficial effects on men's health, including important physiological effects on brain, muscle, bone and fat mass (66). There is accumulating evidence suggesting that androgen deficiency may contribute to the onset and progression of cardiovascular disease and play an important role in the development of the metabolic syndrome in men (67). Interestingly, men with combined vitamin $\mathrm{D}$ and androgen deficiencies are at high risk for all-cause and cardiovascular mortality, suggesting that a parallel deficiency of both hormones is a marker of poor overall health (68). Thus, a causal relationship between vitamin $\mathrm{D}$ and testosterone and in particular a potential increase of testosterone levels after vitamin $\mathrm{D}$ treatment is of high clinical interest.

Testosterone is produced in the Leydig cells following pituitary pulsatile LH secretion, but its production is also modulated by paracrine and autocrine signals supplied by growth factors and cytokines secreted within the testis $(69,70)$. The VDR is almost ubiquitously expressed in human cells, which underlines the clinical significance of the vitamin D endocrine system $(1,2,71)$. VDR and vitamin D-metabolizing enzymes are concomitantly expressed in the entire reproductive male tract, including Leydig cells (72). This VDR expression suggests local autocrine as well as paracrine action of vitamin $\mathrm{D}$ and indicates that vitamin $\mathrm{D}$ is involved in regulation of testis function. Obviously, vitamin D metabolites are locally synthesized and degraded and vitamin D metabolism seems to be regulated by local as well as systemic factors (22). The negative effect of orchiectomy as well as testis dysfunction on circulating $25(\mathrm{OH}) \mathrm{D}$ levels, supports the hypothesis of vitamin D synthesis in the testis $(73,74,75)$.
Of note, it has been shown in an experimental study that mouse Leydig cells basally secrete $25(\mathrm{OH}) \mathrm{D}$, which is also stimulated by human chorionic gonadotropin (hCG) (76). This notion is supported by the fact that hCG treatment in men with late-onset hypogonadism increased circulating $25(\mathrm{OH}) \mathrm{D}$ levels (76). Despite this hypothesis of a local $25(\mathrm{OH}) \mathrm{D}$ production in the testis driven by Leydig cells, the exact regulation of testis vitamin D metabolism is largely unknown. Some evidence suggests that regulatory mechanisms resembling renal vitamin D metabolism exist. These mechanisms include PTH-related molecules and fibroblast growth factor (FGF-23) pathways (22).

Interestingly, it has been shown that androgens increase 1-a-hydroxylase, a key enzyme in vitamin D metabolism that converts $25(\mathrm{OH}) \mathrm{D}$ to $1,25(\mathrm{OH})_{2} \mathrm{D}(77)$. In addition, it has also been demonstrated that the regulation of gene expression by vitamin $\mathrm{D}$ metabolites is modified according to androgen levels (78). On the other hand, vitamin D significantly increased testosterone production in a human primary testicular cell culture model (79). After 1,25(OH) 2 D supplementation, 63 genes were significantly upregulated in human testicular cells, such as IGF-1, ALPL, DPP4 and other bone- and immune system-associated genes (79).

In male VDR-knockout mice, high LH and FSH levels indicate the presence of hypergonadotropic hypogonadism (71). Vitamin D may be critical for testicular function because vitamin D treatment upregulates certain testisspecific genes in mice (35) including ABCA1 (ATP-binding cassette transporter 1). ABCA1-knockout mice have significantly reduced intratesticular testosterone levels as well as reduced sperm counts compared with wild-type animals (80). Experimental studies also indicate that testosterone secretion might be modulated by vitamin D-induced changes in intracellular calcium homeostasis in Leydig cells in animals (22) mediated via calbindinD28k (81). Calbindin-D 28k is a cytosolic calcium-binding protein involved not only in the regulation of intracellular calcium homeostasis but also in testis hormone production (81). Vitamin D effects on testosterone production might also be mediated via osteocalcin, which is produced by osteoblasts and involved in bone metabolism. It has been postulated that vitamin D-induced stimulation of osteocalcin expression might have an indirect relevant role in modulating testosterone production by the testis (22). Further, in humans, a direct stimulatory genomic effect of vitamin D on steroidogenesis enzymes has been postulated (22). http://www.endocrineconnections.org https://doi.org/10.1530/EC-18-0009
(C) 2018 The authors Published by Bioscientifica Ltd
This work is licensed under a Creative Commons Attribution-NonCommercial-NoDerivatives 4.0 International License. 
Table 4 Summary of clinical intervention studies investigating the effects of vitamin D treatment on androgen levels in men.

\begin{tabular}{|c|c|c|c|c|c|}
\hline Author/Study & Study design & Subjects & Age & 25(OH)D levels (baseline) & TT levels (baseline) \\
\hline Pilz et al. (20) & $\mathrm{RCT}$ & $\begin{array}{c}54 \text { obese men (vitamin D } \\
n=31 \text {, placebo } n=23 \text { ) }\end{array}$ & $48.1 \pm 11.1$ years & $\begin{array}{l}<50 \mathrm{nmol} / \mathrm{L} ; \\
31.1 \pm 21.9 \mathrm{nmol} / \mathrm{L}\end{array}$ & $11.4 \mathrm{nmol} / \mathrm{L}$ \\
\hline $\begin{array}{l}\text { Jorde et al. the } \\
\text { Troms } \varnothing \text { study } \\
(84)\end{array}$ & $\begin{array}{l}\text { RCT (pooled } \\
\text { data from } 3 \\
\text { independent } \\
\text { RCTs) }\end{array}$ & $\begin{array}{l}\text { Study } 1 \text { (vitamin D and } \\
\text { obesity): } 129 \text { men with } \\
\text { BMI } 28-47 \mathrm{~kg} / \mathrm{m}^{2} \text {, study } 2 \\
\text { (insulin sensitivity): } 53 \\
\text { men, study } 3 \text { (depression } \\
\text { study): } 100 \text { men }\end{array}$ & $\begin{array}{l}\text { Study } 1: \\
48.9 \pm 10.6 \text { years; } \\
\text { study } 2: \\
51.2 \pm 10.0 \text { years; } \\
\text { study } 3: \\
53.0 \pm 11.1 \text { years }\end{array}$ & $\begin{array}{l}\text { Study } 1: 52.6 \pm 17.8 \mathrm{nmol} / \mathrm{L} \text {, } \\
\text { study } 2: \\
39.9 \pm 14.0 \mathrm{nmol} / \mathrm{L} \\
(25(\mathrm{OH}) \mathrm{D}<50 \mathrm{nmol} / \mathrm{L}) \\
\text { study } 3: \\
45.8 \pm 15.0 \mathrm{nmol} / \mathrm{L} \\
(25(\mathrm{OH}) \mathrm{D} \leq 55 \mathrm{nmol} / \mathrm{L})\end{array}$ & $\begin{array}{l}\text { Study } 1: \\
13.5 \pm 4.2 \mathrm{nmol} / \mathrm{L} \text {, } \\
\text { study } 2: \\
16.9 \pm 6.4 \mathrm{nmol} / \mathrm{L} \text {, } \\
\text { study } 3: \\
14.2 \pm 4.9 \mathrm{nmol} / \mathrm{L}\end{array}$ \\
\hline $\begin{array}{l}\text { Heijboer et al. } \\
(86)\end{array}$ & $\begin{array}{l}\text { RCT (pooled } \\
\text { data from } 3 \\
\text { independent } \\
\text { RCTs) }\end{array}$ & $\begin{array}{l}92 \text { male patients with } \\
\text { heart failure (study 1), } 49 \\
\text { male nursing home } \\
\text { residents (study } 2 \text { ) and } 42 \\
\text { male non-Western } \\
\text { immigrants in the } \\
\text { Netherlands (study 3) }\end{array}$ & $\begin{array}{l}\text { Study 1: } 63 \text { (range } \\
\text { 42-86) years, } \\
\text { study } 2: 82 \\
\text { (range } 71-97 \text { ) } \\
\text { years, study 3: } 53 \\
\text { (range } 20-70 \text { ) } \\
\text { years }\end{array}$ & $\begin{array}{l}\text { Study } 1: 46.5 \text { (38.5- } \\
62.5) \mathrm{nmol} / \mathrm{L}, \text { study } 2: \\
27.0 \text { (23.0-31.5) nmol/L, } \\
\text { study 3: (25OHD <50 } \\
\mathrm{nmol} / \mathrm{L}), 27.5(18-33) \\
\mathrm{nmol} / \mathrm{L}\end{array}$ & $\begin{array}{l}\text { Study } 1: 15 \text { (11-19) } \\
\text { nmol/L, study } 2: \\
11(8-15.8) \\
\text { nmol/L, study } 3: \\
13(11-17) \mathrm{nmol} / \mathrm{L}\end{array}$ \\
\hline Ferlin et al. (99) & $\begin{array}{l}\text { Uncontrolled } \\
\text { intervention } \\
\text { study }\end{array}$ & $\begin{array}{l}20 \text { men with Klinefelter } \\
\text { syndrome (substudy of a } \\
\text { cross-sectional study of } \\
127 \text { Klinefelter men and } \\
60 \text { healthy controls); } 12 \\
\text { men treated with } \\
\text { testosterone + calcifediol } \\
\text { (group 1), } 8 \text { men treated } \\
\text { with calcifediol (group 2) }\end{array}$ & $\begin{array}{l}31.5 \pm 8.5 \text { years } \\
\text { (all } 127 \text { men } \\
\text { with Klinefelter } \\
\text { syndrome) }\end{array}$ & $\begin{array}{l}\text { Baseline } 25(\mathrm{OH}) \mathrm{D} \\
<50 \mathrm{nmol} / \mathrm{L} ; \\
31.3 \pm 8.9 \mathrm{nmol} / \mathrm{L} \text { (group } \\
\text { 1: } \\
\text { testosterone+calcifediol); } \\
23.2 \pm 18.9 \mathrm{nmol} / \mathrm{L} \text { (group } \\
\text { 2: calficediol) }\end{array}$ & $\begin{array}{l}10.5 \pm 4.9 \mathrm{nmol} / \mathrm{L} \\
\text { (all } 127 \text { men with } \\
\text { Klinefelter } \\
\text { syndrome) }\end{array}$ \\
\hline $\begin{array}{l}\text { Foresta et al. } \\
(100)\end{array}$ & $\begin{array}{l}\text { Uncontrolled } \\
\text { intervention } \\
\text { study }\end{array}$ & $\begin{array}{l}66 \text { patients with } \\
\text { hypogonadism (classic } \\
\text { hypogonadism } \\
(\mathrm{TT}<12 \mathrm{nmol} / \mathrm{L}, \mathrm{LH} \geq 8 \mathrm{IU} / \mathrm{L}) \\
(n=26) \text { and subclinical } \\
\text { hypogonadism }(\mathrm{TT} \geq 12 \\
\text { nmol/L, LH } \geq 8 \mathrm{IU} / \mathrm{L}) \\
(n=40))\end{array}$ & $34.5 \pm 6.8$ years & $\begin{array}{l}\text { Baseline } 25(\mathrm{OH}) \mathrm{D} \\
<50 \mathrm{nmol} / \mathrm{L} ; \\
\text { cholecalciferol group : } \\
33.8 \pm 10.5 \mathrm{nmol} / \mathrm{L} ; \\
\text { calcidiol group: } \\
33.4 \pm 9.5 \mathrm{nmol} / \mathrm{L}\end{array}$ & Not given \\
\hline $\begin{array}{l}\text { Canguven et al. } \\
(101)\end{array}$ & $\begin{array}{l}\text { Uncontrolled } \\
\text { intervention } \\
\text { study }\end{array}$ & 102 middle-aged men & $53.2 \pm 10.4$ years & $\begin{array}{l}\text { Baseline } 25(\mathrm{OH}) \mathrm{D} \\
<75 \mathrm{nmol} / \mathrm{L} ; \\
37.9 \pm 11.6 \mathrm{nmol} / \mathrm{L}\end{array}$ & $12.46 \pm 3.30 \mathrm{nmol} / \mathrm{L}$ \\
\hline $\begin{array}{l}\text { Lerchbaum } \\
\text { et al. Graz } \\
\text { Vitamin } \\
\text { D\&TT-RCT } \\
\text { (102) }\end{array}$ & $\mathrm{RCT}$ & $\begin{array}{l}100 \text { healthy men with TT } \\
\text { levels } \geq 10.4 \mathrm{nmol} / \mathrm{L} \\
\text { (vitamin } \mathrm{D} n=50, \text { placebo } \\
n=50 \text { ) }\end{array}$ & $37(27-50)$ years & $\begin{array}{l}<75 \mathrm{nmol} / \mathrm{L} ; 52 \text { (42- } \\
\text { 66) } \mathrm{nmol} / \mathrm{L}\end{array}$ & $\begin{array}{l}18.0(15.8-21.5) \\
\mathrm{nmol} / \mathrm{L}\end{array}$ \\
\hline
\end{tabular}

Data are given as mean \pm S.D. or median (IQR) unless otherwise stated.

25(OH)D, 25 hydroxyvitamin D; BMI, body mass index; IU, international unit; LH, luteinizing hormone; RCT, randomized controlled trial; TT, total testosterone.

http://www.endocrineconnections.org
https://doi.org/10.1530/EC-18-0009 2018 The authors


Primary outcome

Weight loss

Study 1: weight loss, study 2 : change in insulin sensitivity as evaluated with a hyperglycemic glucose clamp study 3: change in

Vitamin D effects on the reninangiotensinaldosterone system (study 1), effects of different vitamin $D$ doses (study 2), and vitamin D effects on insulin sensitivity (study 3) Maintain 25(OH)D levels above $50 \mathrm{nmol} / \mathrm{L}$ depression scores

\section{Study duration}

1 year

Study 1: 1 year study 2:

6 months, study 3: 6 months

Study 1: 40 000 IU/week vitamin D ( 5714IU/day), 20

000 IU/week vitamin D

( 2857 IU/day), or placebo

for 1 year (all subjects: $500 \mathrm{mg}$ calcium/day); study 2 \& 3: 40000 IU vitamin D/ week ( 5714 IU/day) vs placebo for 6 months

Study 1: 6 weeks, study 2: 16 weeks, study 3: 16 weeks

Study 1: 2000 IU/day, study 2: No significant effect

TT levels (study end)

25(OH)D levels (study end) vitamin $D$ group

Significant increase in TT, bioactive testosterone, and FT levels

No significant effect

$86.4 \pm 68.8 \mathrm{nmol} / \mathrm{L}$

600 IU per day, 4200 IU pe week or $18000 \mathrm{lU} / \mathrm{month}$, study 3: $1200 / d$ vs placebo (+500 mg calcium carbonat: all subjects)

2 years

Calcifediol treatment with Didrogyl, Calcifediol starting dose of $4000 \mathrm{lU} /$ week, adjusting the dosage to maintain $25(\mathrm{OH}) \mathrm{D}$ levels $>50 \mathrm{nmol} / \mathrm{L}$, by determining the levels every 6 months

\section{Effects of} cholecalciferol vs calcidiol on $25(\mathrm{OH})$ $D$ levels
5000 IU cholecalciferol per week ( 714 IU/d; $n=20)$ or 4000 IU calcidiol per week ( $571 \mathrm{lU} / \mathrm{d} ; n=36)$
No significant effect

No significant effect
Study 1: $73.5 \mathrm{nmol} / \mathrm{L}$, study 2: $57 \mathrm{nmol} / \mathrm{L}$, study 3: 49 $\mathrm{nmol} / \mathrm{L}$
Group 1: $94.3 \pm 12.9 \mathrm{nmol} / \mathrm{L}$, $\mathrm{nmol} / \mathrm{L}$ group 2: $102.5 \pm 28.7$
Cholecalficerol: $42.6 \pm 11.6 \mathrm{nmol} / \mathrm{L}$; calcidiol: $81.4 \pm 25.0 \mathrm{nmol} / \mathrm{L}$
Significant increase in TT $121.4 \pm 29.1 \mathrm{nmol} / \mathrm{L}$ levels $(12.46 \pm 3.30$ to $15.99 \pm 1.84 \mathrm{nmol} / \mathrm{L}$

\author{
Not specifically \\ biochemical and \\ hormonal \\ parameters as well \\ as on erectile \\ dysfunction) \\ TT measured using \\ mass spectrometry
}

\author{
Men received an initia \\ (Ergocalciferol; oral solution \\ $600000 \mathrm{IU} / 1.5 \mathrm{ml}$ ), and \\ followed a vitamin $D$ \\ treatment regime thereafte
}
20,000 IU/week ( 2,857 IU/ day) vs placebo

No significant effect

107 (89-119) nmol/L http://www.endocrineconnections.org https://doi.org/10.1530/EC-18-0009 (c) 2018 The authors Published by Bioscientifica Ltd

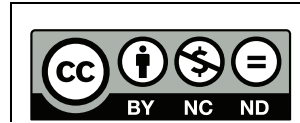

This work is licensed under a Creative Commons Attribution-NonCommercial-NoDerivatives 4.0 International License. 


\section{Observational studies}

In the following paragraph, we will discuss observational studies on vitamin D status and circulating androgen levels in men (summarized in Table 3). The majority of studies found an independent association of vitamin D with circulating androgen levels or hypogonadism in men. In 2011, some of us demonstrated for the first time a significant association of $25(\mathrm{OH}) \mathrm{D}$ and TT levels in men (19). Similarly, Nimptsch and coworkers (82) reported an independent association of $25(\mathrm{OH}) \mathrm{D}$ with TT and FT levels in 1362 male participants of the Health Professionals Follow-up study. Lee and coworkers (83) observed no independent association of TT or FT with 25(OH)D in 3369 community-dwelling men aged 40-79 years from the European Male Aging study. There was, however, an independent association of $25(\mathrm{OH})$ D levels $<50 \mathrm{nmol} / \mathrm{L}$ with compensated as well as with secondary hypogonadism (83). Similarly, Jorde and coworkers (84) found a significant positive association of vitamin D and TT levels (adjusted for age, BMI, season, presence of cardiovascular disease and DM and physical activity) in 893 men from the Tromsø Study. In that study, no significant association was found between $25(\mathrm{OH})$ D and FT, SHBG, FSH or LH (84). In 2854 Chinese men, $25(\mathrm{OH}) \mathrm{D}$ was positively associated with TT and estradiol after adjustments for age, residence area, economic status, smoking, BMI, HOMA-IR, DM and systolic pressure (85). Further, increasing quartiles of $25(\mathrm{OH}) \mathrm{D}$ were associated with significantly decreased odds ratios of hypogonadism (85). Heijboer and coworkers (86) observed a significant positive association of $25(\mathrm{OH}) \mathrm{D}$ and TT levels in 183 men (unadjusted). In addition, a significant positive association of TT and SHBG with 25(OH)D levels was reported in 382 Chinese and Malaysian men (87). The results lost, however, significance after adjustment for BMI (87). Tak and coworkers (88) found an independent association of 25(OH)D levels with TT (adjusted for body fat, WC, BMI, fasting plasma glucose, DM and dyslipidemia) and FT levels (adjusted for age, total muscle mass, smooth muscle mass, total cholesterol, DM, dyslipidemia and alcohol use) in 652 Korean men aged $56.7 \pm 7.9$ years. Further, vitamin D deficiency $(<50 \mathrm{nmol} / \mathrm{L})$ was associated with an increased risk of TT and FT deficiency (adjusting for age, season, BMI, body composition, chronic disease, smoking and alcohol use) (88). Data from the Longitudinal Aging Study Amsterdam, an ongoing population-based cohort study of older Dutch individuals $(n=643)$, documented an independent association of $25(\mathrm{OH}) \mathrm{D}$ levels with TT and bioavailable TT (adjusted for age, BMI, alcohol

$$
\text { http://www.endocrineconnections.org }
$$

consumption, smoking status, season of blood collection, number of chronic diseases, serum creatinine and physical performance) (89). Others reported a significant positive association of $25(\mathrm{OH}) \mathrm{D}$ and TT as well as SHBG in 1315 men (NHANES III) and 318 men (NHANES 2001-2004), respectively (adjusted for age, race/ethnicity, body fat percentage and smoking) (90). Moreover, data from 1427 infertile men indicated lower SHBG and TT/ estradiol ratios but higher FT and estradiol in men with $25(\mathrm{OH}) \mathrm{D}$ levels $<25 \mathrm{nmol} / \mathrm{L}$ compared to men with 25(OH)D levels $>75 \mathrm{nmol} / \mathrm{L}$ (91). The authors observed no independent association of $25(\mathrm{OH}) \mathrm{D}$ levels with hypogonadism, estradiol, SHBG, LH or FSH, respectively (91). In 3016 older men, lower 25(OH)D levels were associated with lower SHBG and higher FT levels after adjusting for demographic and lifestyle variables, whereas no independent association with TT was observed (92).

Some authors failed, however, to demonstrate an independent association of vitamin D and serum androgens in men. Hammoud and coworkers (93) observed no independent association of $25(\mathrm{OH}) \mathrm{D}$ levels with TT or FT levels in 170 healthy men. Similarly, results from NHANES III suggested no significant association of $25(\mathrm{OH})$ D with TT, FT, SHBG or estradiol in 1412 middle-aged men (94). Of note, cross-sectional results from 225 middleaged men suggest a U-shaped association of vitamin D status and risk of hypogonadism (95). In detail, we found a significantly increased risk of hypogonadism in men within the highest $25(\mathrm{OH}) \mathrm{D}$ quintile compared to men in quintile 4 (reference) as well as a trend towards increased risk of hypogonadism in men within the lowest $25(\mathrm{OH}) \mathrm{D}$ quintile. With respect to risk of male hypogonadism, these results suggest optimal serum $25(\mathrm{OH}) \mathrm{D}$ concentrations of $82-102 \mathrm{nmol} / \mathrm{L}$. Those findings as well as previous studies showing no association of vitamin $\mathrm{D}$ and androgens in linear analyses might therefore be supported by previous inconsistent results with possible U-shaped or non-linear associations that have been suggested for vitamin D and cancer (5), cardiovascular disease (96) and mortality $(97,98)$. Furthermore, inconsistent results reported in observational studies might be related to different study populations with respect to sample size, age, comorbidities, ethnicity as well as to various statistical methods used for data analyses.

\section{Intervention studies}

In addition to the above mentioned observational studies, there are some intervention studies evaluating vitamin D effects on androgen levels in men (summarized in Table 4).

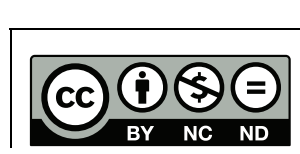
This work is licensed under a Creative Commons
Attribution-NonCommercial-NoDerivatives 4.0 International License. 


\section{Uncontrolled intervention studies}

A small study investigating men with Klinefelter syndrome found no significant effect of vitamin D supplementation (vitamin $\mathrm{D}$ treatment $n=8$, vitamin $\mathrm{D}+$ testosterone treatment $n=12$ ) on androgen levels in men with baseline $25(\mathrm{OH}) \mathrm{D}<50 \mathrm{nmol} / \mathrm{L}(99)$. Similarly, Foresta and coworkers (100) investigated the effect of cholecalciferol (5000 IU per week) ( $n=20)$ or calcidiol (4000 IU per week) $(n=46)$ in 66 patients with hypogonadism and $25(\mathrm{OH}) \mathrm{D}<50 \mathrm{nmol} / \mathrm{L}$ and found no significant effect on TT levels. In contrast, Canguven and coworkers (101) observed a significant increase in TT levels $(12.46 \pm 3.30$ to $15.99 \pm 1.84 \mathrm{nmol} / \mathrm{L})$ in 102 middle-aged men with $25(\mathrm{OH}) \mathrm{D}<75 \mathrm{nmol} / \mathrm{L}$ who received an initial vitamin D dose (Ergocalciferol; oral solution $600,000 \mathrm{IU} / 1.5 \mathrm{~mL}$ ) and followed a vitamin D treatment regime thereafter. Interestingly, the authors observed an increase of erectile dysfunction scores as well as a decrease in estradiol levels after treatment (101).

\section{RCTs}

Evidence from RCTs on vitamin D and TT is sparse. Pilz and coworkers (20) investigated the effects of 1 year of vitamin D supplementation (3332IU daily) on androgens in 54 men (vitamin $\mathrm{D} n=31$, placebo $n=23$ ) undergoing a weight reduction program. The authors observed a significant increase in TT levels, bioactive testosterone levels, and FT levels compared to baseline levels, whereas no significant change was found in the placebo group. The study included men with vitamin D deficiency $(25[\mathrm{OH}] \mathrm{D}<50 \mathrm{nmol} / \mathrm{L})$ and relatively low baseline TT levels $(11.4 \mathrm{nmol} / \mathrm{L})$. Of note, no statistical analysis on treatment effect (between group differences) was performed. In contrast, Heijboer and coworkers (86) failed to find an effect of vitamin D supplementation on serum TT concentrations in 3 independent intervention studies including male patients with heart failure (study 1), male nursing home residents (study 2) and male nonWestern immigrants in the Netherlands (study 3). Those studies were designed to investigate vitamin D effects on the renin-angiotensin-aldosterone system (study 1), effects of different vitamin D doses (study 2) and vitamin D effects on insulin sensitivity (study 3). In study 1, 92 subjects received vitamin D (2000IU daily) or placebo for 6 weeks. In study 2, 49 vitamin D-deficient subjects were randomized to vitamin D (600 IU daily) or placebo for 16 weeks. In study 3, 43 vitamin D-deficient subjects received 1200 IU vitamin D daily or placebo for 16 weeks. Similarly, Jorde and coworkers (84) failed to show a significant vitamin D effect on androgen concentrations
(TT and FT) in pooled data from 3 vitamin D RCTs performed in Tromsø with weight reduction, insulin sensitivity and depression scores as endpoints. In that study, serum $25(\mathrm{OH}) \mathrm{D}$ and androgens were measured in 282 men at baseline and after 6-12 months of vitamin D supplementation (20,000-40,000 IU weekly vs placebo).

Recently, we presented results of the first RCT (Graz Vitamin D\&TT-RCT) designed for the evaluation of vitamin $\mathrm{D}$ effects on serum androgens in men (102). In detail, we randomly assigned 100 men with TT levels $\geq 10.4 \mathrm{nmol} / \mathrm{L}$ and 25(OH)D levels $<75 \mathrm{nmol} / \mathrm{L}$ to receive $20,000 \mathrm{IU} /$ week of vitamin D3 $(n=50)$ or placebo $(n=50)$ for 12 weeks. We found no significant effect on androgen levels in these healthy men with relatively high TT levels at baseline. These results are in line with the Jorde and coworkers (84) as well as with the Heijboer and coworkers study (86) but contradict previous promising findings from the Pilz and coworkers (20) study. Those differences might be related to different study designs and subjects. Although both studies used similar doses (2857 IU/day Lerchbaum and coworkers (102) vs 3332 IU/day Pilz and coworkers (20), respectively), the Graz Vitamin D\&TT-RCT (102) investigated vitamin D effects after 12 weeks vs vitamin D effects after 1 year in the Pilz and coworkers study (20). Further, the Graz Vitamin D\&TT-RCT (102) investigated men with 25(OH) D levels $<75 \mathrm{nmol} / \mathrm{L}$, whereas Pilz and coworkers (20) included subjects with $25(\mathrm{OH}) \mathrm{D}$ levels $<50 \mathrm{nmol} / \mathrm{L}$. Other differences are related to the study participants (healthy men vs significant weight loss in obese subjects), baseline TT levels $(19.1 \mathrm{nmol} / \mathrm{L}$ vs $11.4 \mathrm{nmol} / \mathrm{L})$ and the method used for TT measurements (mass spectrometry vs immunoassay) for the Graz Vitamin D\&TT-RCT report and the Pilz and coworkers study, respectively.

In summary, to date, there is only 1 RCT showing increased androgen levels after vitamin $\mathrm{D}$ supplementation (20); however, vitamin D effects on androgen levels have not been the primary outcome of this study. It should, therefore, be noted that only 1 RCT was specifically designed for the investigation of vitamin D effects on TT levels (102). As this RCT investigated men with relatively high baseline TT levels, a vitamin D effect on TT levels in hypogonadal men or men with low normal TT levels cannot be excluded. This issue is addressed in the second arm of the Graz Vitamin D\&TT-RCT (ClinicalTrials. gov Identifier NCT01748370), results are expected in 2018. Further, the Graz Vitamin D\&TT-RCT investigated a cohort of men with relatively high baseline $25(\mathrm{OH}) \mathrm{D}$ levels. Thus, vitamin D effects in men with severe vitamin $\mathrm{D}$ deficiency cannot be excluded. Given the fact that in healthy middle-aged men a U-shaped association of 
vitamin D levels with hypogonadism has been observed (95), one might speculate that a RCT aiming at target 25(OH)D levels between 75 and $100 \mathrm{nmol} / \mathrm{L}$ would provide different results.

In summary, evidence from RCTs on vitamin D and TT is sparse and revealed conflicting results. We therefore recommend further investigation of potential vitamin D effects on androgen levels in various cohorts including hypogonadal men with severe vitamin D deficiency.

\section{Conclusion}

As outlined above, vitamin D might play an important role in androgen metabolism as well as in metabolic and reproductive processes in PCOS women. Indeed, in PCOS women some RCTs revealed promising results regarding vitamin D effects on metabolic as well as on fertility aspects. Nevertheless, considering previous inconsistent results as well as the large differences in study design and PCOS populations (i.e. PCOS phenotypes), large-scale RCTs in welldefined PCOS populations with clearly defined end points are needed before a general recommendation regarding 25 $(\mathrm{OH}) \mathrm{D}$ measurement and vitamin $\mathrm{D}$ supplementation in PCOS can be made. Similarly, existing evidence from available RCTs evaluating the effect of vitamin D supplementation on androgen levels in men is insufficient to recommend measurement of $25(\mathrm{OH}) \mathrm{D}$ levels or vitamin D supplementation in hypogonadal men. Still, we cannot exclude vitamin $\mathrm{D}$ effects on androgen levels in men with low TT levels or in men with severe vitamin D deficiency. This question remains to be answered in future RCTs.

\section{Declaration of interest}

The authors declare that there is no conflict of interest that could be perceived as prejudicing the impartiality of this review.

\section{Funding}

This review article was supported by funding from The Austrian Science Fund (FWF-KLIF project no.: 274, 2012).

\section{References}

1 Pludowski P, Holick MF, Pilz S, Wagner CL, Hollis BW, Grant WB, Shoenfeld Y, Lerchbaum E, Llewellyn DJ, Kienreich K, et al. Vitamin D effects on musculoskeletal health, immunity, autoimmunity, cardiovascular disease, cancer, fertility, pregnancy, dementia and mortality-a review of recent evidence. Autoimmunity Reviews 201312 976-989. (https://doi.org/10.1016/j.autrev.2013.02.004)

2 Holick MF. Vitamin D deficiency. New England Journal of Medicine 2007357 266-281. (https://doi.org/10.1056/NEJMra070553)
3 Wehr E, Pilz S, Schweighofer N, Giuliani A, Kopera D, Pieber TR \& Obermayer-Pietsch B. Association of hypovitaminosis D with metabolic disturbances in polycystic ovary syndrome. European Journal of Endocrinology 2009161 575-582. (https://doi.org/10.1530/ EJE-09-0432)

4 Pilz S, März W, Wellnitz B, Seelhorst U, Fahrleitner-Pammer A, Dimai HP, Boehm BO \& Dobnig H. Association of vitamin D deficiency with heart failure and sudden cardiac death in a large cross-sectional study of patients referred for coronary angiography. Journal of Clinical Endocrinology and Metabolism 200893 3927-3935. (https://doi.org/10.1210/jc.2008-0784)

5 Pilz S, Kienreich K, Tomaschitz A, Ritz E, Lerchbaum E, ObermayerPietsch B, Matzi V, Lindenmann J, März W, Gandini S, et al. Vitamin D and cancer mortality: systematic review of prospective epidemiological studies. Anti-Cancer Agents in Medicinal Chemistry 201313 107-117. (https://doi.org/10.2174/187152013804487407)

6 Lerchbaum E \& Obermayer-Pietsch B. Vitamin D and fertility-a systematic review. European Journal of Endocrinology 2012166 765-778. (https://doi.org/10.1530/EJE-11-0984)

7 Benyamini Y, Gozlan M \& Kokia E. Variability in the difficulties experienced by women undergoing infertility treatments. Fertility and Sterility 200583 275-283. (https://doi.org/10.1016/j. fertnstert.2004.10.014)

8 Thonneau P, Marchand S, Tallec A, Ferial ML, Ducot B, Lansac J, Lopes P, Tabaste JM \& Spira A. Incidence and main causes of infertility in a resident population $(1,850,000)$ of three French regions (1988-1989). Human Reproduction 19916 811-816. (https:// doi.org/10.1093/oxfordjournals.humrep.a137433)

9 Lerchbaum E, Schwetz V, Giuliani A \& Obermayer-Pietsch B. Hypertriglyceridemic waist is associated with impaired glucose tolerance in polycystic ovary syndrome. Nutrition, Metabolism and Cardiovascular Diseases 201323 e15-e16. (https://doi.org/10.1016/j. numecd.2012.11.004)

10 Wehr E, Gruber HJ, Giuliani A, Möller A, Pieber TR \& ObermayerPietsch B. The lipid accumulation product is associated with impaired glucose tolerance in PCOS women. Journal of Clinical Endocrinology and Metabolism 201196 E986-E990. (https://doi. org/10.1210/jc.2011-0031)

11 Legro RS, Arslanian SA, Ehrmann DA, Hoeger KM, Murad MH, Pasquali R \& Welt CK. Diagnosis and treatment of polycystic ovary syndrome: an Endocrine Society Clinical Practice Guideline. Journal of Clinical Endocrinology and Metabolism 201398 4565-4592. (https:// doi.org/10.1210/jc.2013-2350)

12 Wehr E, Pieber TR \& Obermayer-Pietsch B. Effect of vitamin D3 treatment on glucose metabolism and menstrual frequency in PCOS women-a pilot study. Journal of Endocrinological Investigation 201134 757-763.

13 Forti G \& Krausz C. Clinical review 100: evaluation and treatment of the infertile couple. Journal of Clinical Endocrinology and Metabolism 199883 4177-4188. (https://doi.org/10.1210/jcem.83.12.5296)

14 Zitzmann M. Testosterone deficiency, insulin reistance and the metabolic syndrome. Nature Reviews Endocrinology 20095 673-681. (https://doi.org/10.1038/nrendo.2009.212)

15 Khaw KT, Dowsett M, Folkerd E, Bingham S, Wareham N, Luben R, Welch A \& Day N. Endogenous testosterone and mortality due to all causes, cardiovascular disease, and cancer in men: European prospective investigation into cancer in Norfolk (EPIC-Norfolk) Prospective Population Study. Circulation $20071162694-2701$. (https://doi.org/10.1161/CIRCULATIONAHA.107.719005)

16 Laughlin GA, Barrett-Connor E \& Bergstrom J. Low serum testosterone and mortality in older men. Journal of Clinical Endocrinology and Metabolism 200893 68-75. (https://doi. org/10.1210/jc.2007-1792)

17 Wehr E, Pilz S, Boehm BO, März W, Grammer TB \& ObermayerPietsch B. Sex steroids and mortality in men referred for coronary angiography. Clinical Endocrinology 201073 613-621. (https://doi. org/10.1111/j.1365-2265.2010.03852.x)

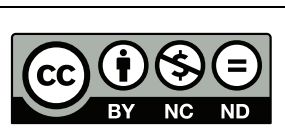

This work is licensed under a Creative Commons Attribution-NonCommercial-NoDerivatives 4.0 International License. 
18 Wehr E, Pilz S, Boehm BO, März W, Grammer T \& ObermayerPietsch B. Low free testosterone is associated with heart failure mortality in older men referred for coronary angiography. European Journal of Heart Failure 201113 482-488. (https://doi.org/10.1093/ eurjhf/hfr007)

19 Wehr E, Pilz S, Boehm BO, März W \& Obermayer-Pietsch B. Association of vitamin D status with serum androgen levels in men Clinical Endocrinology 201073 243-248. (https://doi.org/10.1111/ j.1365-2265.2009.03777.x)

20 Pilz S, Frisch S, Koertke H, Kuhn J, Dreier J, Obermayer-Pietsch B, Wehr E \& Zittermann A. Effect of vitamin D supplementation on testosterone levels in men. Hormone and Metabolic Research 201143 223-225. (https://doi.org/10.1055/s-0030-1269854)

21 Lerchbaum E \& Rabe T. Vitamin D and female fertility. Current Opinion in Obstetrics and Gynecology 201426 145-150. (https://doi. org/10.1097/GCO.0000000000000065)

22 de Angelis C, Galdiero M, Pivonello C, Garifalos F, Menafra D, Cariati F, Salzano C, Galdiero G, Piscopo M, Vece A, et al. The role of vitamin D in male fertility: a focus on the testis. Reviews in Endocrine and Metabolic Disorders 201718 285-305. (https://doi.org/10.1007/ s11154-017-9425-0)

23 Weisman Y, Harell A, Edelstein S, David M, Spirer Z \& Golander A. 1 alpha, 25-Dihydroxyvitamin D3 and 24,25-dihydroxyvitamin D3 in vitro synthesis by human decidua and placenta. Nature 1979281 317-319. (https://doi.org/10.1038/281317a0)

24 Parikh G, Varadinova M, Suwandhi P, Araki T, Rosenwaks Z, Poretsky L \& Seto-Young D. Vitamin D regulates steroidogenesis and insulin-like growth factor binding protein-1 (IGFBP-1) production in human ovarian cells. Hormone and Metabolic Research 201042 754-757. (https://doi.org/10.1055/s-0030-1262837)

25 Barrera D, Avila E, Hernández G, Halhali A, Biruete B, Larrea F \& Díaz L. Estradiol and progesterone synthesis in human placenta is stimulated by calcitriol. Journal of Steroid Biochemistry and Molecular Biology 2007103 529-532. (https://doi.org/10.1016/j. jsbmb.2006.12.097)

26 Irani M \& Merhi Z. Role of vitamin D in ovarian physiology and its implication in reproduction: a systematic review. Fertility and Sterility 2014102 460-468. (https://doi.org/10.1016/j.fertnstert.2014.04.046)

27 Zec I, Tislaric-Medenjak D, Megla ZB \& Kucak I. Anti-Müllerian hormone: a unique biochemical marker of gonadal development and fertility in humans. Biochemical Medicine 201121 219-230. (https:// doi.org/10.11613/BM.2011.031)

28 Dennis NA, Houghton LA, Jones GT, van Rij AM, Morgan K \& McLennan IS. The level of serum anti-Müllerian hormone correlates with vitamin D status in men and women but not in boys. Journal of Clinical Endocrinology and Metabolism 201297 2450-2455. (https:// doi.org/10.1210/jc.2012-1213)

29 Wehr E, Trummer O, Giuliani A, Gruber HJ, Pieber TR \& ObermayerPietsch B. Vitamin D-associated polymorphisms are related to insulin resistance and vitamin D deficiency in polycystic ovary syndrome. European Journal of Endocrinology 2011 164 741-749. (https://doi. org/10.1530/EJE-11-0134)

30 He C, Lin Z, Robb SW \& Ezeamama AE. Serum vitamin D levels and polycystic ovary syndrome: a systematic review and meta-analysis. Nutrients 20157 4555-4577. (https://doi.org/10.3390/nu7064555)

31 Thomson RL, Spedding S \& Buckley JD. Vitamin D in the aetiology and management of polycystic ovary syndrome. Clinical Endocrinology 201277 343-350. (https://doi.org/10.1111/j.13652265.2012.04434.x)

32 Belenchia AM, Tosh AK, Hillman LS \& Peterson CA. Correcting vitamin D insufficiency improves insulin sensitivity in obese adolescents: a randomized controlled trial. American Journal of Clinical Nutrition 201397 774-781. (https://doi.org/10.3945/ ajcn.112.050013

33 Tzotzas T, Papadopoulou FG, Tziomalos K, Karras S, Gastaris K, Perros P \& Krassas GE. Rising serum 25-hydroxy-vitamin D levels after weight loss in obese women correlate with improvement in insulin resistance. Journal of Clinical Endocrinology and Metabolism 201095 4251-4257. (https://doi.org/10.1210/jc.2010-0757)

34 Selimoglu H, Duran C, Kiyici S, Ersoy C, Guclu M, Ozkaya G, Tuncel E, Erturk E \& Imamoglu S. The effect of vitamin D replacement therapy on insulin resistance and androgen levels in women with polycystic ovary syndrome. Journal of Endocrinological Investigation 201033 234-238. (https://doi.org/10.1007/BF03345785)

35 Rajakumar K, de las Heras J, Chen TC, Lee S, Holick MF \& Arslanian SA. Vitamin D status, adiposity, and lipids in black American and Caucasian children. Journal of Clinical Endocrinology and Metabolism 201196 1560-1567. (https://doi.org/10.1210/ jc.2010-2388)

36 Oliveira RM, Novaes JF, Azeredo LM, Cândido AP \& Leite IC. Association of vitamin D insufficiency with adiposity and metabolic disorders in Brazilian adolescents. Public Health Nutrition 201417 787-794. (https://doi.org/10.1017/S1368980013001225)

37 Vimaleswaran KS, Berry D, Lu C, Tikkanen E, Pilz S, Hiraki LT, Cooper JD, Dastani Z, Li R, Houston DK, et al. Causal relationship between obesity and vitamin D status: bi-directional Mendelian randomization analysis of multiple cohorts. PLoS Medicine 201310 e1001383. (https://doi.org/10.1371/journal.pmed.1001383)

$38 \mathrm{Li}$ HW, Brereton RE, Anderson RA, Wallace AM \& Ho CK. Vitamin $\mathrm{D}$ deficiency is common and associated with metabolic risk factors in patients with polycystic ovary syndrome. Metabolism 201160 1475-1481. (https://doi.org/10.1016/j.metabol.2011.03.002)

39 Maestro B, Molero S, Bajo S, Dávila N \& Calle C. Transcriptional activation of the human insulin receptor gene by 1,25-dihydroxyvitamin D(3). Cell Biochemistry and Function 200220 227-232. (https://doi.org/10.1002/cbf.951)

40 Maestro B, Dávila N, Carranza MC \& Calle C. Identification of a vitamin $\mathrm{D}$ response element in the human insulin receptor gene promoter. Journal of Steroid Biochemistry and Molecular Biology $2003 \mathbf{8 4}$ 223-230. (https://doi.org/10.1016/S0960-0760(03)00032-3)

41 Mitri J, Muraru MD \& Pittas AG. Vitamin D and type 2 diabetes: a systematic review. European Journal of Clinical Nutrition 201165 1005-1015. (https://doi.org/10.1038/ejcn.2011.118)

42 Mahmoudi T. Genetic variation in the vitamin D receptor and polycystic ovary syndrome risk. Fertility and Sterility 200992 1381-1383. (https://doi.org/10.1016/j.fertnstert.2009.05.002)

43 Ranjzad F, Mahban A, Shemirani AI, Mahmoudi T, Vahedi M, Nikzamir A \& Zali MR. Influence of gene variants related to calcium homeostasis on biochemical parameters of women with polycystic ovary syndrome. Journal of Assisted Reproduction and Genetics 201128 225-232. (https://doi.org/10.1007/s10815-010-9506-4)

44 Zadeh-Vakili A, Ramezani Tehrani F, Daneshpour MS, Zarkesh M, Saadat N \& Azizi F. Genetic polymorphism of vitamin D receptor gene affects the phenotype of PCOS. Gene 2013515 193-196. (https://doi.org/10.1016/j.gene.2012.11.049)

45 Moghetti P. Insulin resistance and polycystic ovary syndrome. Current Pharmaceutical Design 201622 5526-5534. (https://doi.org/10 .2174/1381612822666160720155855)

46 Mishra S, Das AK \& Das S. Hypovitaminosis D and associated cardiometabolic risk in women with PCOS. Journal of Clinical and Diagnostic Research 201610 BC01-BC04.

47 Pal L, Zhang H, Williams J, Santoro NF, Diamond MP, Schlaff WD Coutifaris C, Carson SA, Steinkampf MP, Carr BR, et al. Vitamin D status relates to reproductive outcome in women with polycystic ovary syndrome: secondary analysis of a multicenter randomized controlled trial. Journal of Clinical Endocrinology and Metabolism 2016 101 3027-3035. (https://doi.org/10.1210/jc.2015-4352)

48 Joham AE, Teede HJ, Cassar S, Stepto NK, Strauss NK, Strauss BJ, Harrison CL, Boyle J \& de Courten B. Vitamin D in polycystic ovary syndrome: relationship to obesity and insulin resistance. Molecular Nutrition and Food Research 201660 110-118. (https://doi. org/10.1002/mnfr.201500259)

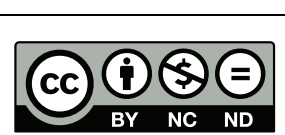

This work is licensed under a Creative Commons Attribution-NonCommercial-NoDerivatives 4.0 International License. 
49 Kim JJ, Choi YM, Chae SJ, Hwang KR, Yoon SH, Kim MJ, Kim SM, Ku SY, Kim SH \& Kim JG. Vitamin D deficiency in women with polycystic ovary syndrome. Clinical and Experimental Reproductive Medicine 201441 80-85. (https://doi.org/10.5653/ cerm.2014.41.2.80)

50 Kumar A, Barki S, Raghav V, Chaturvedi A \& Kumar KVSH. Correlation of vitamin D with metabolic parameters in polycystic ovary syndrome. Journal of Family Medicine and Primary Care 20176 115-119. (https://doi.org/10.4103/2249-4863.214985)

51 Sahin S, Eroglu M, Selcuk S, Turkgeldi L, Kozali S, Davutoglu S \& Muhcu M. Intrinsic factors rather than vitamin D deficiency are related to insulin resistance in lean women with polycystic ovary syndrome. European Review for Medical and Pharmacological Sciences 201418 2851-2856.

52 Ott J, Wattar L, Kurz C, Seemann R, Huber JC, Mayerhofer K \& Vytiska-Binstorfer E. Parameters for calcium metabolism in women with polycystic ovary syndrome who undergo clomiphene citrate stimulation: a prospective cohort study. European Journal of Endocrinology 2012166 897-902. (https://doi.org/10.1530/EJE-111070)

53 Jamilian M, Foroozanfard F, Rahmani E, Talebi M, Bahmani F \& Asemi Z. Effect of two different doses of vitamin d supplementation on metabolic profiles of insulin-resistant patients with polycystic ovary syndrome. Nutrients 20179 E1280. (https://doi.org/10.3390/ nu9121280)

54 Foroozanfard F, Talebi M, Samimi M, Mehrabi S, Badehnoosh B, Jamilian M, Maktabi M \& Asemi Z. Effect of two different doses of vitamin D supplementation on metabolic profiles of insulin-resistant patients with polycystic ovary syndrome: a randomized, doubleblind, placebo-controlled trial. Hormone and Metabolic Research 2017 49 612-617. (https://doi.org/10.1055/s-0043-112346)

55 Maktabi M, Chamani M \& Asemi Z. The effects of vitamin D supplementation on metabolic status of patients with polycystic ovary syndrome: a randomized, double-blind, placebo-controlled trial. Hormone and Metabolic Research 201749 493-498. (https://doi. org/10.1055/s-0043-107242)

56 Raza-Khan N, Shah J, Stetter CM, Lott ME, Kunselman AR, Dodson WC \& Legro RS. High-dose vitamin D supplementation and measures of insulin sensitivity in polycystic ovary syndrome: a randomized, controlled pilot trial. Fertility and Sterility $2014 \mathbf{1 0 1}$ 1740-1175. (https://doi.org/10.1016/j.fertnstert.2014.02.021)

57 Garg G, Kachhawa G, Ramot R, Khadgawat R, Tandon N, Sreenivas V, Kriplani A \& Gupta N. Effect of vitamin D supplementation on insulin kinetics and cardiovascular risk factors in polycystic ovary syndrome: a pilot study. Endocrine Connections 20154 108-116. (https://doi.org/10.1530/EC-15-0001)

58 Irani M, Minkoff H, Seifer DB \& Merhi Z. Vitamin D increases serum levels of the soluble receptor for advanced glycation end products in women with PCOS. Journal of Clinical Endocrinology and Metabolism 201499 E886-E890. (https://doi.org/10.1210/jc.2013-4374)

59 Irani M, Seifer DB, Grazi RV, Julka N, Bhatt D, Kalgi B, Irani S, Tal O, Lambert-Messerlian G \& Tal R. Vitamin D supplementation decreases TGF- $\beta 1$ bioavailability in PCOS: a randomized placebo-controlled trial. Journal of Clinical Endocrinology and Metabolism 2015100 4307-4314. (https://doi.org/10.1210/jc.2015-2580)

60 Irani M, Seifer DB, Grazi RV, Irani S, Rosenwaks Z \& Tal R. Vitamin D decreases serum VEGF correlating with clinical improvement in vitamin D-deficient women with PCOS: a randomized placebocontrolled trial. Nutrients 20179 E334. (https://doi.org/10.3390/ nu9040334)

61 Razavi M, Jamilian M, Karamali M, Bahmani F, Aghadavod E \& Asemi Z. The effects of vitamin D-K-Calcium co-supplementation on endocrine, inflammation, and oxidative stress biomarkers in vitamin D-deficient women with polycystic ovary syndrome: a randomized, double-blind, placebo-controlled trial. Hormone and Metabolic Research 201648 446-451. (https://doi.org/10.1055/s-0042-104060)
62 Asadi M, Matin N, Frootan M, Mohamadpour J, Qorbani M \& Tanha FD. Vitamin D improves endometrial thickness in PCOS women who need intrauterine insemination: a randomized doubleblind placebo-controlled trial. Archives of Gynecology and Obstetrics 2015289 865-870. (https://doi.org/10.1007/s00404-013-3055-x)

63 Xue Y, Xu P, Xue K, Duan X, Cao J, Luan T, Li Q \& Gu L. Effect of vitamin $\mathrm{D}$ on biochemical parameters in polycystic ovary syndrome women: a meta-analysis. Archives of Gynecology and Obstetrics 2017 295 487-496. (https://doi.org/10.1007/s00404-016-4247-y)

64 Fang F, Ni K, Cai Y, Shang J, Zhang X \& Xiong C. Effect of vitamin D supplementation on polycystic ovary syndrome: a systematic review and meta-analysis of randomized controlled trials. Complementary Therapies in Clinical Practice 201726 53-60. (https:// doi.org/10.1016/j.ctcp.2016.11.008)

65 Azadi-Yazdi M, Nadjarzadeh A, Khosravi-Boroujeni H \& SalehiAbargouei A. The effect of vitamin D supplementation on the androgenic profile in patients with polycystic ovary syndrome: a systematic review and meta-analysis of clinical trials. Hormone and Metabolic Research 201749 174-179. (https://doi. org/10.1055/s-0043-103573)

66 Karagiannis A \& Harsoulis F. Gonadal dysfunction in systemic diseases. European Journal of Endocrinology 2005152 501-513. (https://doi.org/10.1530/eje.1.01886)

67 Traish AM, Saad F, Feeley RJ \& Guay A. The dark side of testosterone deficiency: III. Cardiovascular disease. Journal of Andrology 200930 477-494. (https://doi.org/10.1210/jc.2013-2350)

68 Lerchbaum E, Pilz S, Boehm BO, Grammer TB, Obermayer-Pietsch B \& März W. Combination of low free testosterone and low vitamin D predicts mortality in older men referred for coronary angiography. Clinical Endocrinology 201277 475-483. (https://doi.org/10.1111/ j.1365-2265.2012.04371.x)

69 O'Shaughnessy PJ. Hormonal control of germ cell development and spermatogenesis. Seminars in Cell and Developmental Biology 201429 $55-65$.

70 Ramaswamy S \& Weinbauer GF. Endocrine control of spermatogenesis: role of FSH and LH/testosterone. Spermatogenesis 20154 e996025. (https://doi.org/10.1080/21565562.2014.996025)

71 Kinuta K, Tanaka H, Moriwake T, Aya K, Kato S \& Seino Y. Vitamin $\mathrm{D}$ is an important factor in estrogen biosynthesis of both female and male gonads. Endocrinology 2000141 1317-1324. (https://doi. org/10.1210/endo.141.4.7403)

72 Blomberg Jensen M. Vitamin D and male reproduction. Nature Reviews Endocrinology 201410 175-186. (https://doi.org/10.1038/ nrendo.2013.262)

73 Foresta C, Selice R, De Toni L, Di Mambro A, Carraro U, Plebani M $\&$ Garolla A. Altered bone status in unilateral testicular cancer survivors: role of CYP2R1 and its luteinizing hormone-dependency. Journal of Endocrinological Investigation 201336 379-384. (https://doi. org/10.1007/BF03347112)

74 Foresta C, Selice R, Di Mambro A \& Strapazzon G. Testiculopathy and vitamin D insufficiency. Lancet 2010376 1301. (https://doi. org/10.1016/S0140-6736(10)61916-2)

75 Schepisi G, De Padova S, Scarpi E, Lolli C, Gurioli G, Menna C, Burgio SL, Rossi L, Gallà L, Casadio V, et al. Vitamin D status among long-term survivors of testicular cancer. Oncotarget 20178 36780-36786.

76 De Toni L, De Filippis V, Tescari S, Ferigo M, Ferlin A, Scattolini V, Avogaro A, Vettor R \& Foresta C. Uncarboxylated osteocalcin stimulates 25-hydroxy vitamin D production in Leydig cell line through a GPRC6a-dependent pathway. Endocrinology 2014155 4266-4274. (https://doi.org/10.1210/en.2014-1283)

77 Somjen D, Katzburg S, Stern N, Kohen F, Sharon O, Limor R, Jaccard N, Hendel D \& Weisman Y. 25 hydroxy-vitamin D(3)-1alpha hydroxylase expression and activity in cultured human osteoblasts and their modulation by parathyroid hormone, estrogenic compounds and dihydrotestosterone. Journal of Steroid Biochemistry

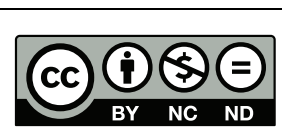

This work is licensed under a Creative Commons Attribution-NonCommercial-NoDerivatives 4.0 International License. 
and Molecular Biology 2007107 238-244. (https://doi.org/10.1016/j. jsbmb.2007.03.048)

78 Mordan-McCombs S, Brown T, Wang WL, Gaupel AC, Welsh J \& Tenniswood M. Tumor progression in the LPB-tag transgenic model of prostate cancer is altered by vitamin $\mathrm{D}$ receptor and serum testosterone status. Journal of Steroid Biochemistry and Molecular Biology 2010121 368-371. (https://doi.org/10.1016/j.jsbmb.2010.03.062)

79 Hofer D, Münzker J, Schwetz V, Ulbing M, Hutz K, Stiegler P, Zigeuner R, Pieber TR, Müller H \& Obermayer-Pietsch B. Testicular synthesis and vitamin D action. Journal of Clinical Endocrinology and Metabolism 201499 3766-3773. (https://doi.org/10.1210/jc.20141690)

80 Selva DM, Hirsch-Reinshagen V, Burgess B, Zhou S, Chan J, McIsaac S, Hayden MR, Hammond GL, Vogl AW \& Wellington CL. The ATP-binding cassette transporter 1 mediates lipid efflux from Sertoli cells and influences male fertility. Journal of Lipid Research 200445 1040-1050. (https://doi.org/10.1194/jlr.M400007-JLR200)

81 Kagi U, Chafouleas JG, Norman AW \& Heizmann CW. Developmental appearance of the $\mathrm{Ca} 2+-$ binding proteins parvalbumin, calbindin D-28K, S-100 proteins and calmodulin during testicular development in the rat. Cell and Tissue Research 1988252 359-365.

82 Nimptsch K, Platz EA, Willett WC \& Giovannucci E. Association between plasma $25-\mathrm{OH}$ vitamin $\mathrm{D}$ and testosterone levels in men. Clinical Endocrinology 201277 106-112. (https://doi.org/10.1111/ j.1365-2265.2012.04332.x)

83 Lee DM, Tajar A, Pye SR, Boonen S, Vanderschueren D, Bouillon R, O’Neill TW, Bartfai G, Casanueva FF, Finn JD, et al. Association of hypogonadism with vitamin D status: the European Male Ageing Study. European Journal of Endocrinology 2012166 77-85. (https://doi. org/10.1530/EJE-11-0743)

84 Jorde R, Grimnes G, Hutchinson MS, Kjærgaard M, Kamycheva E \& Svartberg J. Supplementation with vitamin d does not increase serum testosterone levels in healthy males. Hormone and Metabolic Research 201345 675-681. (https://doi.org/10.1055/s-0033-1345139)

85 Wang N, Han B, Li Q, Chen Y, Chen Y, Xia F, Lin D, Jensen MD \& $\mathrm{Lu}$ Y. Vitamin D is associated with testosterone and hypogonadism in Chinese men: results from a cross-sectional SPECT-China study. Reproductive Biology and Endocrinology 201413 74. (https://doi. org/10.1186/s12958-015-0068-2)

86 Heijboer AC, Oosterwerff M, Schroten NF, Eekhoff EM, Chel VG, de Boer RA, Blankenstein MA \& Lips P. Vitamin D supplementation and testosterone concentrations in male human subjects. Clinical Endocrinology 201583 105-110. (https://doi.org/10.1111/cen.12711)

87 Chin KY, Ima-Nirwana S \& Wan Ngah WZ. Vitamin D is significantly associated with total testosterone and sex hormone-binding globulin in Malaysian men. Aging Male 201518 175-179. (https://doi.org/10.3 109/13685538.2015.1034686)

88 Tak YJ, Lee JG, Kim YJ, Park NC, Kim SS, Lee S, Cho BM, Kong EH, Jung DW \& Yi YH. Serum 25-hydroxyvitamin D levels and testosterone deficiency in middle-aged Korean men: a cross-sectional study. Asian Journal of Andrology 201517 324-328. (https://doi. org/10.4103/1008-682X.142137)

89 Rafiq R, van Schoor NM, Sohl E, Zillikens MC, Oosterwerff MM, Schaap L, Lips P \& de Jongh RT. Associations of vitamin D status and vitamin D-related polymorphisms with sex hormones in older men. Journal of Steroid Biochemistry and Molecular Biology 2016164 11-17. (https://doi.org/10.1016/j.jsbmb.2015.11.013)

90 Anic GM, Albanes D, Rohrmann S, Kanarek N, Nelson WG, Bradwin G, Rifai N, McGlynn KA, Platz EA \& Mondul AM.
Association between serum 25-hydroxyvitamin D and serum sex steroid hormones among men in NHANES. Clinical Endocrinology 201685 258-266. (https://doi.org/10.1111/cen.13062)

91 Blomberg Jensen M, Gerner Lawaetz J, Andersson AM, Petersen JH, Nordkap L, Bang AK, Ekbom P, Joensen UN, Prætorius L, Lundstrøm P, et al. Vitamin D deficiency and low ionized calcium are linked with semen quality and sex steroid levels in infertile men. Human Reproduction 201631 1875-1885. (https://doi.org/10.1093/ humrep/dew152)

92 Zhao D, Ouyang P, de Boer IH, Lutsey PL, Farag YM, Guallar E, Siscovick DS, Post WS, Kalyani RR, Billups KL, et al. Serum vitamin D and sex hormones levels in men and women: the Multi-Ethnic Study of Atherosclerosis (MESA). Maturitas 201796 95-102. (https://doi. org/10.1016/j.maturitas.2016.11.017)

93 Hammoud AO, Meikle AW, Peterson CM, Stanford J, Gibson M \& Carrell DT. Association of 25-hydroxy-vitamin D levels with semen and hormonal parameters. Asian Journal of Andrology 201214 855-859. (https://doi.org/10.1038/aja.2012.77)

94 Wulaningsih W, Van Hemelrijck M, Michaelsson K, Kanarek N, Nelson WG, Ix JH, Platz EA \& Rohrmann S. Association of serum inorganic phosphate with sex steroid hormones and vitamin D in a nationally representative sample of men. Andrology 20142 967-976. (https://doi.org/10.1111/andr.285)

95 Lerchbaum E, Pilz S, Trummer C, Rabe T, Schenk M, Heijboer AC \& Obermayer-Pietsch B. Serum vitamin D levels and hypogonadism in men. Andrology 20142 748-754. (https://doi.org/10.1111/j.20472927.2014.00247.x)

96 Wang TJ, Pencina MJ, Booth SL, Jacques PF, Ingelsson E, Lanier K, Benjamin EJ, D'Agostino RB, Wolf M \& Vasan RS. Vitamin D deficiency and risk of cardiovascular disease. Circulation 2008117 503-511. (https://doi.org/10.1161/ CIRCULATIONAHA.107.706127)

97 Sempos CT, Durazo-Arvizu RA, Dawson-Hughes B, Yetley EA, Looker AC, Schleicher RL, Cao G, Burt V, Kramer H, Bailey RL, et al. Is there a reverse $\mathrm{J}$-shaped association between 25 -hydroxyvitamin $\mathrm{D}$ and all-cause mortality? Results from the U.S. nationally representative NHANES. Journal of Clinical Endocrinology and Metabolism 201398 3001-3009. (https://doi.org/10.1210/jc.2013-1333)

98 Zittermann A, Iodice S, Pilz S, Grant WB, Bagnardi V \& Gandini S. Vitamin D deficiency and mortality risk in the general population: a meta-analysis of prospective cohort studies. American Journal of Clinical Nutrition 201295 91-100. (https://doi.org/10.3945/ ajcn.111.014779)

99 Ferlin A, Selice R, Di Mambro A, Ghezzi M, Di Nisio A, Caretta N \& Foresta C. Role of vitamin D levels and vitamin D supplementation on bone mineral density in Klinefelter syndrome. Osteoporosis International 201526 2193-2202. (https://doi.org/10.1007/s00198015-3136-8)

100 Foresta C, Calogero AE, Lombardo F, Lenzi A \& Ferlin A. Late-onset hypogonadism: beyond testosterone. Asian Journal of Andrology 2015 17 236-238. (https://doi.org/10.4103/1008-682X.135985)

101 Canguven O, Talib R, El Ansari W, Yassin DJ \& Al Naimi A. Vitamin D treatment improves levels of sexual hormones, metabolic parameters and erectile function in middle-aged vitamin D deficient men. Aging Male 201720 9-16. (https://doi.org/10.1080/13685538.2016.1271783)

102 Lerchbaum E, Pilz S, Trummer C, Schwetz V, Pachernegg O, Heijboer AC \& Obermayer-Pietsch B. Vitamin D and testosterone in healthy men: a randomized controlled trial. Journal of Clinical Endocrinology and Metabolism 2017102 4292-4302. (https://doi. org/10.1210/jc.2017-01428)

Received in final form 29 January 2018

Accepted 15 February 2018

Accepted Preprint published online 15 February 2018 http://www.endocrineconnections.org https://doi.org/10.1530/EC-18-0009
() 2018 The authors Published by Bioscientifica Ltd

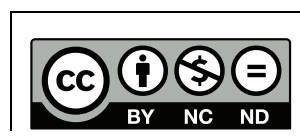

This work is licensed under a Creative Commons Attribution-NonCommercial-NoDerivatives 4.0 International License. 